\title{
Egy emlős mesterséges kromoszóma több génnel történő feltöltésének új módszere
}

\author{
Ph. D. értekezés \\ Tóth Anna \\ Témavezető: Dr. Katona Róbert \\ Biológia Doktori Iskola \\ MTA SZBK Genetikai Intézet
}

SZTE-TTIK

2014.

Szeged 


\section{Tartalomjegyzék}

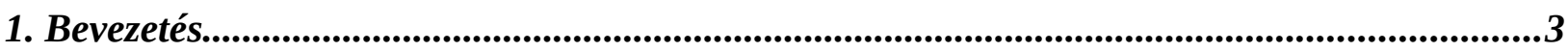

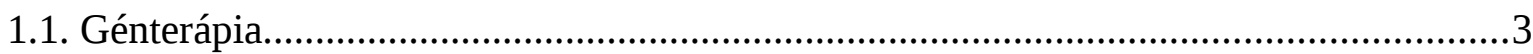

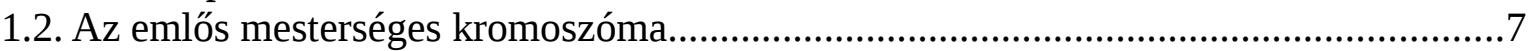

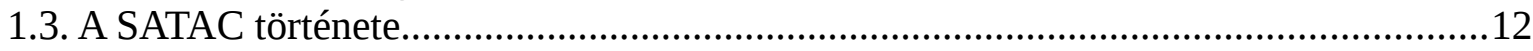

1.4. Példák az emlős mesterséges kromoszóma rendszer alkalmazására.............................19

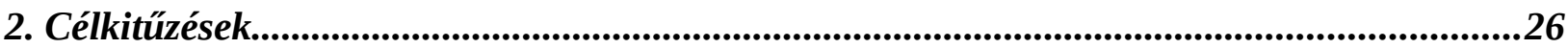

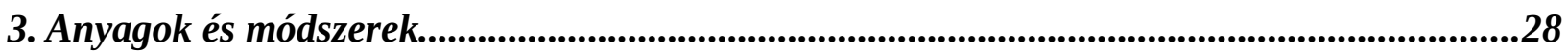

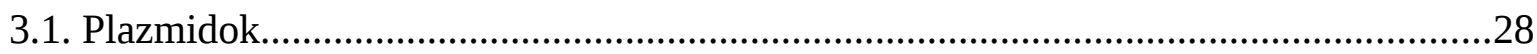

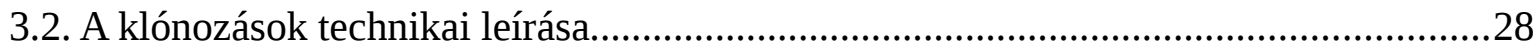

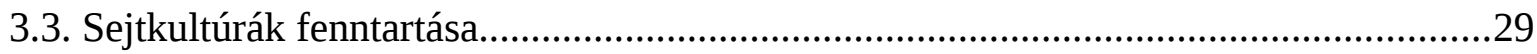

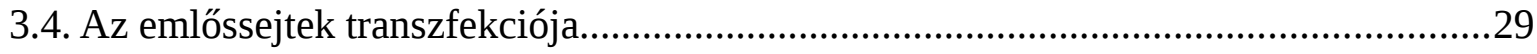

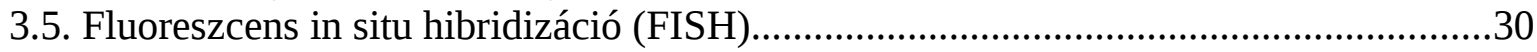

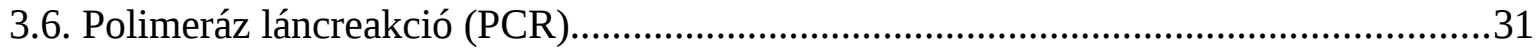

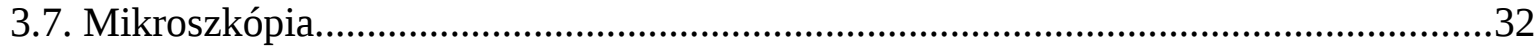

3.8. Béta-galaktozidáz enzim kimutatása sejttenyészetekben.......................................33

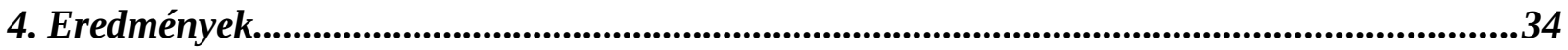

4.1. Egy szelekciós markergén kazettát hordozó vektor létrehozása.................................34

4.2. A szupertöltési kísérletekhez szükséges plazmid konstrukciók előállítása és ellenőrzése

4.3. A szupertöltő ciklus 1. lépése: mCherry fehérjét a mesterséges kromoszómáról

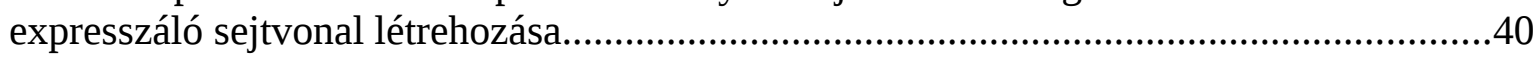

4.4. A szelekciós markergén kazetta eltávolítása Cre rekombináz segítségével.................42

4.5. A szupertöltő ciklus 2. lépése: béta-galaktozidáz gént hordozó plazmid konstrukció

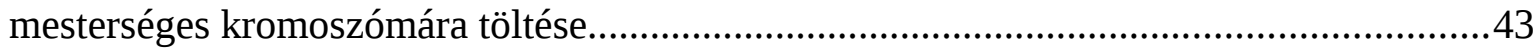

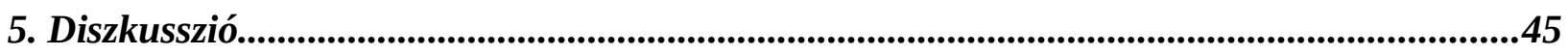

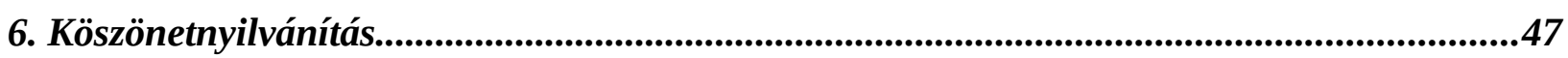

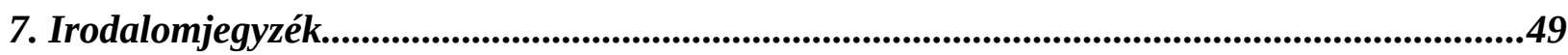

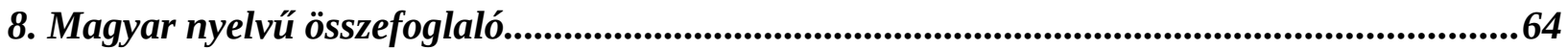

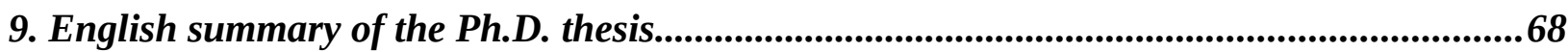




\section{Bevezetés}

\subsection{Génterápia}

A génterápia mindazon gyógyító célú beavatkozásokat jelenti, amelyek egy adott betegség megelőzését vagy kezelését, illetve a tünetek enyhítését funkcionális genetikai információ bevitelével kívánja elérni (1, 74). A génterápia napjainkban a klinikai gyakorlat viharos gyorsasággal fejlődő, nagy érdeklődéstől övezett, egyben legvitatottabb területe. Amint egyre több olyan gén válik ismertté, amelynek mutációja, hibás müködése betegséget okoz, úgy egyre sürgetőbb az igény az orvoslásra: az öröklött vagy szerzett betegségek kezelésére, gyógyítására, illetve megelőzésére.

A génterápia a sejtek molekuláris szintű folyamataiba avatkozik be, genetikai információ bevitelével célirányosan megváltoztatva azokat. Így a géntechnológia speciális területének is tekinthetjük. A hibás gének cseréje, illetve javítása elvileg mind a szomatikus, mind a csírasejtekben megtörténhet:

a) a szomatikus (testi sejtekre irányuló) génterápia $(2,64)$ a meglévő betegségek vagy betegségre hajlamosító állapotokat okozó hibás gén kijavítását jelenti. A génterápiának ezt a formáját már nem övezik nagy viták. A módszer biztonságossága körül vannak aggodalmak, de etikai ellenvetés már nincsen. A szomatikus sejtekben végzett génterápia bár nem öröklődik, az egyén életében segíthet akár egy, akár több gén okozza a betegséget. A monogénes betegségek egy gén meghibásodása miatt alakulnak ki. Ezek közül ma már többnek is ismerjük a kromoszómális elhelyezkedését és pontos funkcióját. Ezért ezeknek a betegségeknek a kezelése - elvileg - a 
rendelkezésünkre álló génterápiás eszközökkel megvalósítható. Ilyenek például az egyes anyagcsere rendellenességek (pl.: Gaucher-kór), az izomdisztrófiák (pl.: Duchenne), vagy egyes hematológiai betegségek (bizonyos leukémiák, sarlósejtes anémia, hemofíliák) (43, 44). Ugyancsak monogénesek az elsődleges immundefektusok (ㅁevere combined îmmunodeficiency; SCID) (40) vagy a cisztás fibrózis (41). A több gén okozta betegségek (pl.: cukorbetegség) prognózisát a legtöbb esetben nagyban befolyásolják a környezeti tényezők is. Ezért ezekben az esetekben a genetikai anyag módosításával, még ha lehetséges is lenne, nem feltétlenül várható a teljes gyógyulás. Így a génterápiás kísérletek - legalábbis jelenleg - a monogénes betegségekre szorítkoznak. Néhány esetben bizonyították, hogy bizonyos malignus tumorok kialakulása szintén egy-egy gén mutációjának köszönhető (108). Ezért a halálozási statisztikák élén álló rosszindulatú daganatos betegségek kiemelt célpontjai lehetnek ezeknek a próbálkozásoknak. A daganat kifejlődése előtt a génhibák kimutatása és helyreállítása ugyanis megakadályozhatná, ideális esetben megelőzhetné a tumor későbbi kialakulását. Az autoimmun betegségek ugyancsak a génterápia célpontjainak tekinthetők. Ezekben a kórképekben a szervezet immunsejtjei megtámadják a saját egészséges sejteket, így azok károsodhatnak vagy akár el is pusztulhatnak. Gyógyulást csak a kóros immunválaszban résztvevő vagy azok célpontjául szolgáló gének/géncsoportok módosításával érhetünk el.

b) az ivarsejtek génterápiája, azaz az utódnemzedékre átadódó, öröklődő változások létrehozása - bár az ember esetében tabunak, tiltott dolognak számít - a növény- és állatvilágban már manapság is alkalmazott technológia: nemesítésre, terméshozam növelésére, ellenálló képesség fokozására, stb.

A géntechnológiát/génterápiát tudományos szempontból sem lehet alulbecsülni. A transzgenikus 
növények és állatok páratlan lehetőséget nyújtanak a gének és a génmúködés megismerésére, igazi tudományos aranybányáknak tekinthetjük őket.

Akár szomatikus, akár ivarsejtben történő beavatkozásról legyen is szó, az új információt be kell juttatni a sejtekbe. Ez történhet hordozó vagy más néven vektor molekulák segítségével vagy fizikai módszerekkel. A gének hibás múködéséből eredő betegségek kezelésére, illetve gyógyítására elvileg három lehetőség kínálkozik: 1) a hibás gén (amely vagy hibás fehérjét eredményez vagy egyáltalán nem képződik fehérje) eltávolítása után egy alkalmas módszerrel a helyesen múködő változatot bevinni, 2) a hibás gén szekvenciájában bekövetkezett hibát/hibákat kijavítani, 3) egy hibátlan, múködőképes gént bejuttatni a sejtbe a hibás változat meghagyásával.

Manapság hordozóként vagy vektorként leggyakrabban genetikailag módosított vírusok használatosak (retrovírus, adenovírus, adeno-asszociált vírusok, herpes vírusok, alfavírusok, poxvírusok). A génterápia ezekben az esetekben toxikus, vagy immunogén is lehet a sejtekre. A vírus-alapú vektorok korlátozott transzgén hordozó kapacitással rendelkeznek, de a legnagyobb probléma az, hogy integrálódhatnak a gazdasejt örökítő anyagába, ami a későbbiekben például daganatképződést indíthat be (42). A génterápia legismertebb példája a SCID betegek vírus-alapú vektorokkal végzett gyógyítása volt. A leggyakoribb formája az X-kromoszómához kötött öröklődésmenetű úgynevezett X-hez kötött súlyos kombinált immundeficiencia. A betegségre

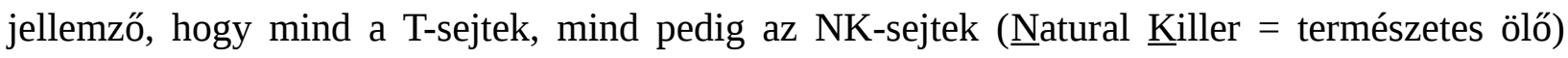
száma csökkent, míg a B-sejtek száma normális vagy enyhén emelkedett. A '90-es évek elején kimutatták, hogy a betegség a több citokin receptorhoz (IL-2, IL-4, IL-7, IL-9, és IL-15 receptorok) is kötődő gamma lánc (gamma-C) fehérjét kódoló génben bekövetkező mutációk miatt alakul ki. Az X-SCID egy halálos kórkép, általában a betegek az első életévükben 
meghalnak. Csontvelő átültetés segítségével sikeresen kezelhető a betegség, de sajnos nagyon ritkán sikerül megfelelő donort találni. Ezért a betegséget megkísérelték génterápiával gyógyítani úgy, hogy a páciensek csontvelőjéből vérképző őssejteket nyertek ki, melyekbe bejuttatták a hibás gamma-C működő változatát. A módosított vírusokkal végzett terápia eredményes és a mai napig az egyetlen gyógymód azokban az esetekben, ahol nem találnak donort a csontvelő átültetéshez. Az utóbbi időben azonban kiderült, hogy a kezelésnek súlyos mellékhatása is lehet. Néhány évvel a kezelés után több fiatal X-SCID betegnél leukémiát diagnosztizáltak, amelyet bizonyíthatóan a beteg örökítő anyagába beépült vírus vektor okozott (109).

A leggyakrabban alkalmazott virális és nem-virális beviteli rendszerek főbb tulajdonságait az $\mathbf{1}$. táblázat mutatja be.

\begin{tabular}{|c|c|c|c|c|c|c|}
\hline & \multicolumn{3}{|c|}{ VIRÁLIS GÉNBEVITEL } & \multicolumn{3}{|c|}{ NEM-VIRÁLIS GÉNBEVITEL } \\
\hline & $\begin{array}{c}\text { NEM-INTEGRÁLÓDÓ } \\
\text { VÍRUS VEKTOROK }\end{array}$ & $\begin{array}{l}\text { INTEGR } \\
\text { VÍRUS VE }\end{array}$ & $\begin{array}{l}\text { ÁLÓDÓ } \\
\text { KTOROK }\end{array}$ & & & \\
\hline & Adenovírus & Retrovírus & Lentivírus & $\begin{array}{l}\text { Liposzóma vagy polimer } \\
\text { mediált génbevitel }\end{array}$ & Elektroporáció & Mesterséges kromoszóma \\
\hline Befogadóképeség (kb) & $8-10$ & 8 & 9 & $\sim 200$ & $\sim 2000$ & $3 \mathrm{Mb}$ \\
\hline $\begin{array}{c}\text { Kromoszómális } \\
\text { integráció }\end{array}$ & előfordulhat & van & van & van & van & nincs \\
\hline Immunogén hatás & van & van & van & nincs & nincs & nincs \\
\hline Toxikus hatás & van & van & van & van & van & nincs \\
\hline $\begin{array}{l}\text { Lehetséges génterápiás } \\
\text { alkalmazás }\end{array}$ & $\begin{array}{c}\text { ornithine transcarbamylase, } \\
\text { cisztás fibrózis kezelése }\end{array}$ & $\begin{array}{l}\text { X-SCID, } \\
\text { ADA-SCID } \\
\text { kezelése }\end{array}$ & $X-S C I D$ & $\begin{array}{c}\text { daganatos megbetegedések } \\
\text { kezelése }\end{array}$ & $\begin{array}{l}\text { daganatos } \\
\text { megbetegedések } \\
\text { kezelése }\end{array}$ & $\begin{array}{c}\text { Krabbe-betegség, } \\
\text { Duchenne izomdisztrófia kezelése } \\
\text { (preklinikai adatok) }\end{array}$ \\
\hline
\end{tabular}

\section{1. táblázat. A génterápiában alkalmazott virális és nem-virális beviteli rendszerek főbb}

tulajdonságai (Táblázat forrása: Engineering targeted viral vectors for gene therapy, Reinhard Waehler, Stephen J. Russel \& David T. Curiel, Nature Reviews Genetics 8,573-587, August 2007).

A nem-vírus alapú rendszerekben a terápiás gént vagy zsírcseppekbe (liposzómákba) vagy polimerekbe csomagolva juttatják be a sejtekbe. Amennyiben ezeket a módszereket alkalmazzák, 
azzal is számolni kell, hogy a bevitel iránya nem kontrollálható (mivel random integráció lehetséges) és hatékonysága alacsony.

A génterápia gyakorlati alkalmazásának egyik legnagyobb problémája, hogy a genetikai információt kódoló géneket célba juttató, jelenleg rendelkezésre álló hordozó eszközöknek számos hiányossága van. Az ideális vektor főbb jellemzői az alábbiakkal foglalhatók össze:

- ne tartalmazzon olyan DNS-elemeket, amelyek nem kívánatos megváltozása (rekombináció, mutáció) az érintett sejt, szövet vagy szervezet müködését károsan befolyásolja;

- ne épüljön be a kromoszómákba, a génállomány normális működését ne befolyásolja;

- biztosítsa az általa szállított gén(ek) szabályozott működését és (számuk) ellenőrizhetőségét, azaz állandóságát;

- illetve alkalmas legyen nagy méretű (akár több Mb hosszúságú) gének befogadására, bevitelére és működésük biztosítására.

E szigorú feltételeket mai ismereteink szerint egyetlen jelenleg használatban lévő mesterséges génhordozó sem elégíti ki. Új korszakot nyithat azonban az emlős mesterséges kromoszóma, mint lehetséges génterápiás vektor. A vírus-alapú vektorok hiányosságaival szemben (alacsony hordozó kapacitás, a gazdagenomba történő integráció) az emlős mesterséges kromoszóma szinte korlátlan méretű DNS befogadására képes, valamint nem integrálódik (3-11).

\subsection{Az emlős mesterséges kromoszóma}

A mesterséges kromoszómák létrehozásának jelenleg négy fő stratégiáját ismerjük (45): (1) 
szintetikus vagy „bottom up” megközelítés, amelyben kromoszómális komponenseket illesztenek össze de novo (110-120), (2) „top down” módszer, amely a már meglévő kromoszómák telomer-asszociált in vivo fragmentációját tűzi ki célul (12, 13, 17, 18, 19, 46, 92, 93, 94, 95, 96, 121), (3) természetesen előforduló minikromoszómák módosításával történő mesterséges kromoszóma előállítás (98) és (4) indukált de novo kromoszóma létrehozása specifikus kromoszómális fragmentek amplifikációjával (3-8, 99). Napjainkig a „top down” megközelítéssel és az indukált de novo kromoszóma képzéssel állítottak elő olyan emlős mesterséges kromoszóma rendszereket ( $\triangle \mathrm{HAC}$ és ACE rendszer), amelyek biotechnológiai felhasználásra alkalmasak lehetnek (10).

A $\triangle$ HAC rendszer mesterséges kromoszómáit a humán 21-es kromoszóma rövid és hosszú karjainak egymást követő „csonkításával” hozták létre (1. ábra/a). Ezen mesterséges kromoszómák egy LoxP helyet hordoznak, amely inszerciós helyként szolgál, ha transzgént töltünk fel a Cre-rekombináz által mediált Cre/LoxP rendszer segítségével (46). Az 1. ábra/b a $\triangle$ HAC rendszer müködését mutatja be. 


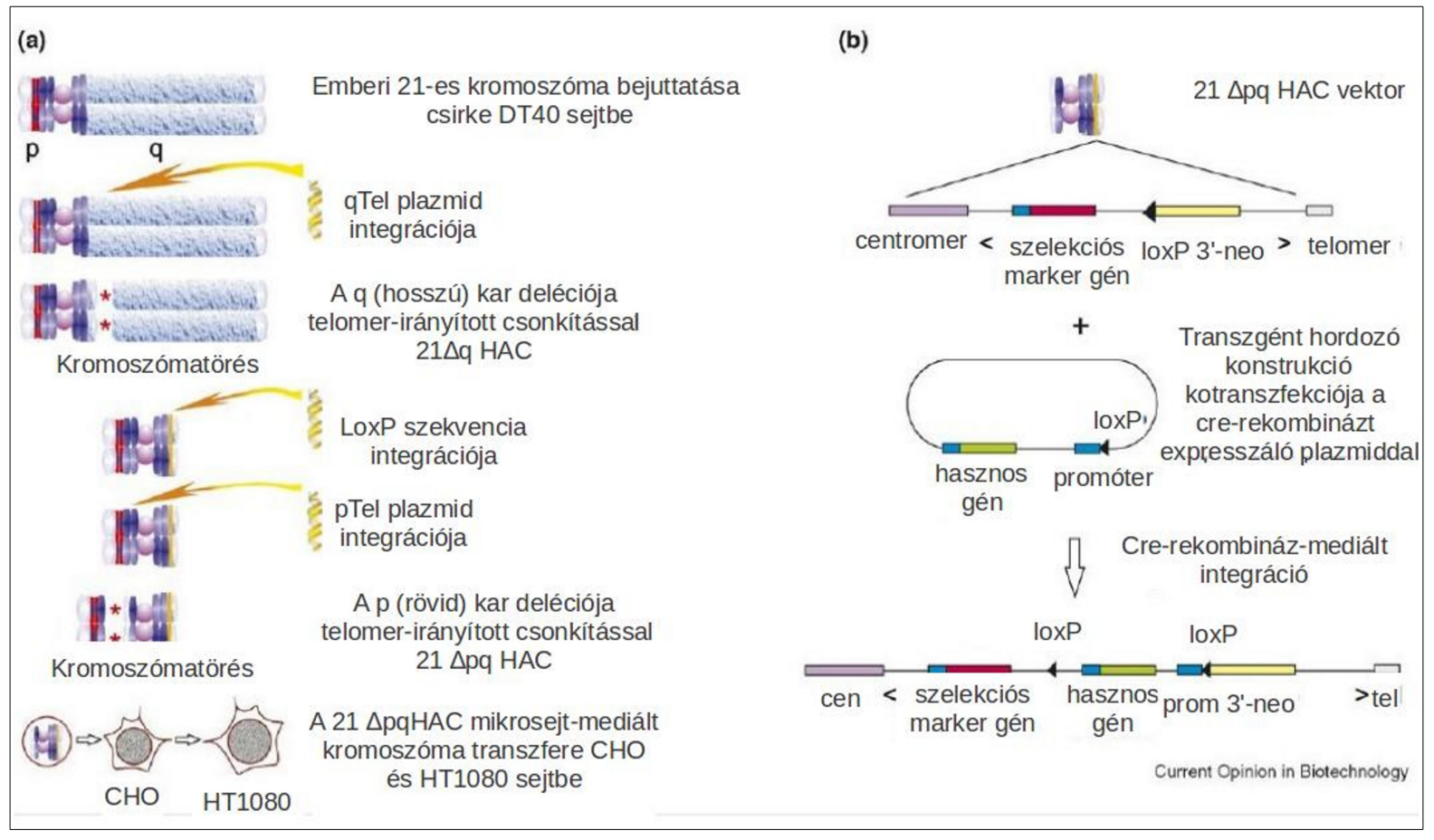

1. ábra. A $\triangle H A C$ rendszer müködésének alapelvei. a) A 21 ApqHAC vektor előállítása. b) Transzgén "feltöltése" a 21 1 pqHAC vektorra. (Kép forrása: Duncan, A. and Hadlaczky, G. Chromosomal engineering. Curr. Opin. Biotechnol 18, 420-424 (2007).)

A Cre-rekombináz rendszerek hátrányát az emlős genomokban jelenlévő funkcionális felismerő helyek megléte (inszerciós mutagenezishez vezethet), illetve az alacsony hatékonyság jelentik (122). A kromoszómák „csonkítása” és a $\Delta$ HAC-ok hatékony létrehozása általában a kromoszómák csirke DT40 sejtekbe történő bejuttatását igényli, alacsony hatékonyságú módszerekkel, például sejtfúzióval vagy mikrosejt-mediált módon.

A mesterséges kromoszóma expressziós rendszer $(\mathrm{ACE}$ system $=$ Artificial $\underline{\text { Chromosome }}$ Expression system) a szatellit DNS-alapú mesterséges kromoszómákra (SATACs) épül (5, 7). A SATAC-okat az akrocentrikus kromoszómák rövid karjának nagyléptékű, indukált amplifikációja hozza létre (2. ábra/a), amely akár 50-nél is több amplikon létrejöttét eredményezheti. A transzfektált DNS által okozott replikációs hiba indítja el a nagyléptékű amplifikációt, amelynek 
eredményeként identikus, tandem elrendezésű blokkokból felépül egy új kromoszómakar, egy új centromer, végül létrejön egy új, csak riboszómális géneket hordozó, szatellit DNS-ből álló mesterséges kromoszóma (innen az elnevezés). Ez a kromoszóma az említett DNS elemeken kívül így kizárólag csak az(oka)t a müködő gén(eke)t és szekvenciákat hordozza, amit a transzfektált DNS-sel juttattunk a sejtbe. Az új kromoszómának a sejtekben való megjelenése egyúttal azt is jelenti, hogy sikeresen túljutott a „minőségellenőrzésen”, hiszen a sejtosztódások során csakis a szerkezetileg ép, és müködőképes SATAC maradhat fenn. Ahhoz, hogy a SATAC vektorként múködhessen, fogadóhelyekre van szükség, ahová a „hasznos” géneket be lehet építeni. Az ACE rendszer már feltöltő helyekkel rendelkező kromoszóma. A transzgén(ek) „feltöltése” egy módosított lambda integráz (ACE integráz) segítségével történik, amelynek akceptor helyei (attP) számos kópiában (50-200) megtalálhatók a mesterséges kromoszómán (8, 105, 106, 107). Az ACE integrázt korábban úgy állították elő, hogy a lambda integráz enzim génjét polimeráz láncreakcióval a lambda bakteriofág DNS-éből amplifikálták. A körülbelül 1 kilobázis méretű amplifikált fragmentet pUC19 vektorba klónozták. A keletkezett plazmidban pontmutációt hoztak létre a lambda integráz kódoló szekvenciájában, a 174-es pozícióban lévő glutamint lizinné változtatták (E174R). Ennek köszönhetően az enzim nemcsak bakteriális környezetben $(\mathbf{5 6}, \mathbf{5 7})$ képes rekombinációt katalizálni, hanem emlőssejtekben is $(\mathbf{5 8 , 5 9 , 6 0 )}$. A módosított lambda integráz szekvenciát ezt követően átklónozták a pCX-EGFP plazmidba az eGFP régió helyére, így hozták létre a pCXLamIntR elnevezésű plazmidot. A pCXLamIntR vektort ezután úgy módosították, hogy egy optimalizált emlős Kozak szekvenciát $(\mathbf{6 1}, \mathbf{6 2})$ illesztettek bele, és a létrehozott plazmidot pCXLamIntROK-nak nevezték el. Ez az a vektor, amelyet a hasznos gént hordozó plazmiddal együtt transzfektálunk a mesterséges kromoszómát hordozó sejtvonalba. Ez biztosítja az integráz enzim expresszióját, amely az általunk feltölteni kívánt gént a kromoszóma megfelelő fogadóhelyeire helyspecifikus integrációval bejuttatja (8). 
Ez úgy történik, hogy az enzim a mesterséges kromoszómán lévő attP és a targetáló vektoron lévő attB felismerési helyek között képes rekombinációt katalizálni. Az ACE rendszer múködését a 2. ábra/b mutatja be.

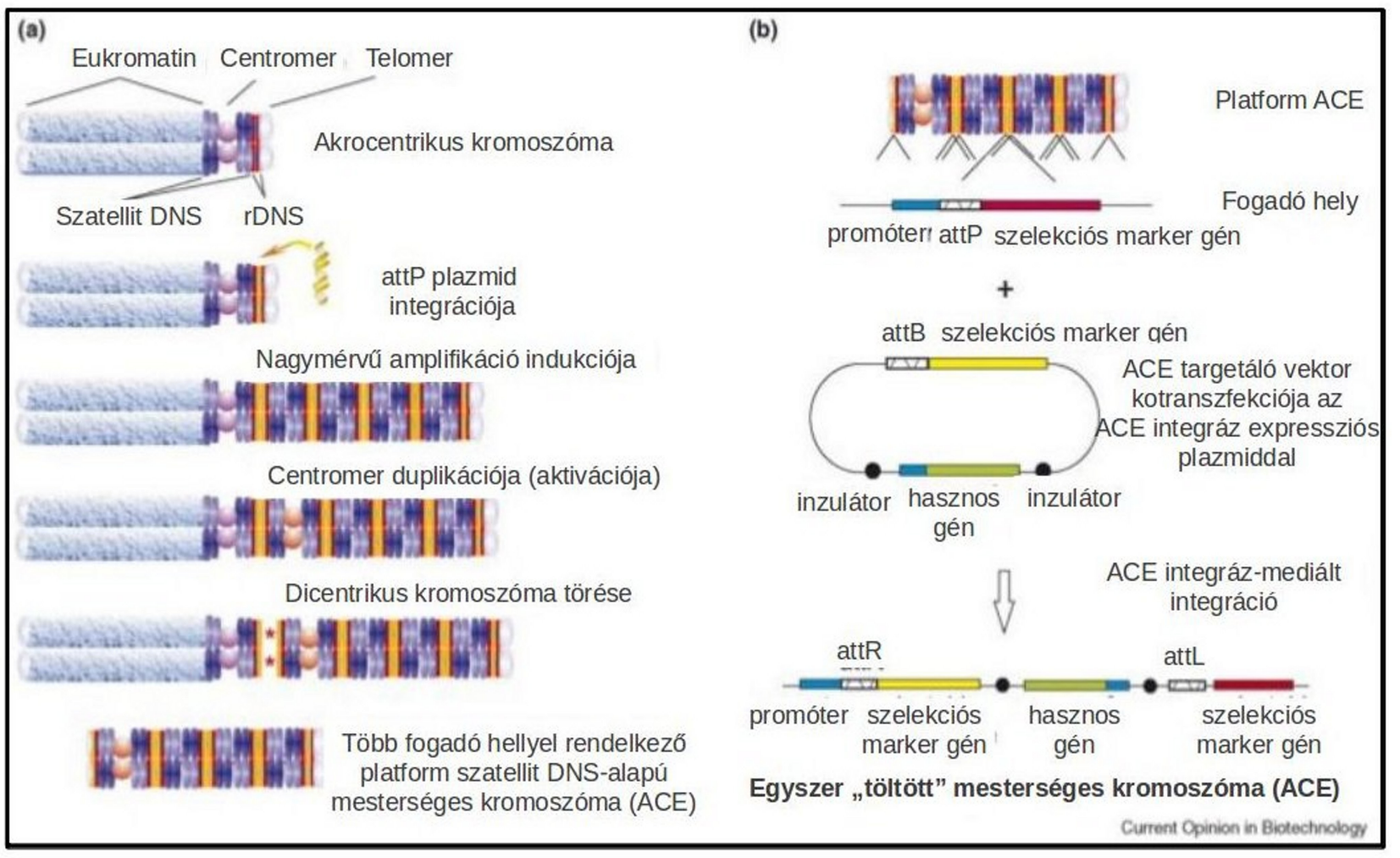

2. ábra. Az ACE rendszer müködésének alapelvei. a) A szatellit DNS-alapú mesterséges kromoszóma (SATAC) létrehozása. b) Egy transzgén „feltöltése” a platform mesterséges kromoszómára (ACE). (Kép forrása: Duncan, A. and Hadlaczky, G. Chromosomal engineering. Curr. Opin. Biotechnol 18, 420-424 (2007).)

Az ACE rendszert potenciális vektornak tekinthetjük, mert:

- Nagy transzgén hordozó kapacitással rendelkezik, mind a gének méretét, mind a számukat illetően.

- A módosított lambda integráz rendszer hatékonyan múködik a transzgén(ek) kromoszómára töltésében (60-95\%-os hatékonyság a sejttípustól függően). 
- A transzgénen és a riboszómális géneken kívül nem hordoz géneket.

- Stabilan, akár nem-szelektív körülmények között is fennmaradnak a sejtekben, mind a mitózis, mind pedig a meiózis során.

- A bevitt transzgén(ek) kitűnően expresszálódnak (akár 1g/liter humán monoklonális IgG1 ellenanyag termelés is elérhető) a SATAC-ról $(\mathbf{1 2 3 , 1 2 4 ) .}$

- Segítségével transzgenikus állatot lehet létrehozni. Kiderült, hogy a SATAC a transzgenikus állatokban öröklődik és sikerült bizonyítani, hogy a szatellit DNS alapú mesterséges kromoszómák jelenléte semmilyen észrevehető „mellékhatást” nem idéz elő az élőlényekben.

• Ismételhetően és hatékonyan előállítható, akár különböző „hasznos” génekkel is felszerelve.

- Szekvencia összetétele (AT gazdag szekvencia) és mérete alapján jól tisztítható (7, 20). Jelenleg az ACE rendszer SATAC-jait tudják egyedül megfelelő mennyiségben (és gyakorlatilag 100\%-os tisztaságban), áramlási citometria segítségével tisztítani. Ugyanezt a $\triangle$ HAC rendszer kromoszómáiról nem mondhatjuk el, legfőképpen a kis méretük miatt.

\subsection{A SATAC története}

A centromer az eukarióta kromoszómák speciális régiója, amely a kinetochor képződés helyéül szolgál és fontos szerepe van az eukarióta kromoszómák magasabb rendű szerveződésében is (47, 65). Alacsonyabb rendű eukarióták (élesztő) centromerjét már az 1980-as években sikeresen 
izolálták és telomerrel kombinálva élesztő mesterséges kromoszómákat (YAC = $\underline{\text { Yeast }}$ Artificial Chromosome) hoztak létre $(\mathbf{6 6}, \mathbf{6 7})$. Az emlős mesterséges kromoszómák létrehozásához kulcsfontosságú lenne a centromer izolálása és klónozása, azaz a molekuláris szerkezet és működés megértése. A magasabb rendű eukarióta sejtek a centromer két oldalán repetitív DNS szekvenciákat - pericentrikus heterokromatint - hordoznak. Ezeknek az ismétlődő szakaszoknak egy részét eddig sem szekvenálni, sem izolálni, sem klónozni nem sikerült.

Hadlaczky Gyula és munkatársai 1991-ben immunkémiai stratégiával, anti-centromer ellenanyagot használva kísérelték meg izolálni a humán centromert. A centromerikus régióról köztudott, hogy strukturálisan az emlőskromoszómák legstabilabb része. Ellenáll az enzimatikus kezeléseknek és bizonyos fokig a mechanikai nyírásnak is (68). Ezért az emberi osztódó sejttenyészetből izolált kromoszómákról részlegesen eltávolították a hiszton fehérjéket és DNázA enzimmel kezelték őket. Ezzel kívánták biztosítani, hogy az anti-centromer ellenanyagok hozzáférjenek a centromerikus szakaszokhoz, illetve az azokba zárt DNS-hez. Az eljárás sikerrel járt és az izolált DNS szakaszok klónozásával vagy ezeket próbaként alkalmazva, humán genomikus könyvtárból (69) nagy mennyiségű feltételezett centromer DNS-t izoláltak. Bakteriofág „szigetelő” DNS szakaszok és egy szelektálható markergénnel történt összeépítést követően megkezdődtek a DNS beviteli kísérletek, egérsejtekbe történő transzfekcióval (70). A '90-es évek elejére megszülettek az első sejtvonalak, amelyek újonnan képződött, önálló, kisebbnagyobb kromoszómákat hordoztak, gyakran extra centromerrel. A kialakult dicentrikus kromoszóma „eredeti” és „új” centromerje megkülönböztethetetlen volt az anti-centromer ellenanyagokkal végzett immunfestések alapján. A dicentrikus kromoszómák szabályos törése (2. ábra/a) és a minikromoszómák képződése alapján feltételezhető, hogy az extra centromerek is képesek a mitotikus orsóhoz kötődni. Az eredeti és az új centromer ellentétes irányú elmozdulása 
pedig a kromoszóma töréséhez vezet. A kísérletek során létrehozott sejtvonalakban az extra centromer működőképesnek, és nem-szelektív körülmények között is stabilnak bizonyult (3). Ez ellentmond annak az irodalmi adatnak, amely szerint ha két centromer van jelen egy kromoszómán, akkor az egyik biztosan nem múködik (71).

A centromerikus DNS szekvenciák izolálása és a kromoszómaképződés jelensége ismételhetőnek bizonyult. Sőt a minikromoszómák méretét többszörösen meghaladó, „óriás”, akár több száz Mb hosszúságú kromoszómákat hordozó sejtvonalakat is sikerült előállítani. Ez olyan DNS transzfekciójával is sikerült, amely nem tartalmazott feltételezett centromerikus DNS-t (4). Nyilvánvalóvá vált, hogy a centromer és a kromoszómaképződés nem a bevitt DNS specifikus bázissorrendjétől függ. A további vizsgálatra kiválasztott „megakromoszóma” körülbelül 150200 Mb hosszúságú volt és bizonyítottan hét amplikon tandem elrendeződéséből állt, melyeket egér eredetű repetitív szekvenciák határoltak. A 30 Mb méretű amplikonokat két nagy ( 15 Mb méretű) fordított ismétlődés alkotta. Az ilyen fordított kromoszóma szegmensek kialakulásáról - amelyek az emlős DNS szekvenciák nagyléptékű amplifikációjának következtében jöttek létre - az irodalomban több helyen is olvashatunk (75, 76, 77, 78, 79, 80). Egy 1996-ban megjelent tanulmány arról számol be, hogy ezek a szegmensek az egérkromoszómák centromerikus régiójának magasabbrendű replikációs egységét reprezentálják (6). Kiderült, hogy a replikáció az egérkromoszómák pericentrikus heterokromatinjában és centromerjében kezdődik. Ezért azt feltételezték, hogy egy replikáció által irányított mechanizmus lehet felelős az egérkromoszómák centromerikus régiójában bekövetkező nagyléptékű amplifikációért, illetve az új, stabil kromoszómák képződéséért is. Egy átlagos emlőssejtben megtalálható DNS 10000-60000 replikonba rendeződik, melyek mindegyike rendelkezik egy replikációs kiinduló ponttal vagy replikátorral (81), illetve egy DNS-fehérje 
komplex-szel, amely a replikációt iniciálja. Az emlőskromoszómák kétirányú replikációja a sejtciklus S-fázisa során több pontról is kiindulhat (82). Az emlőssejtekben a replikáció kiindulópontjai sokáig tisztázatlanok voltak, de a kínai hörcsög ovárium sejtek amplifikált dihydrofolát reduktáz génjének vizsgálata a replikáció kiindulópontjának megismeréséhez vezetett (83). Pár évvel később Kitsberg és munkatársai meghatározták az emberi béta-globin génben a replikáció kiindulópontját (84). Ezek voltak azok a főbb irodalmi adatok, amelyek alapján bizonyították a replikátorok jelenlétét az emlőssejtekben (85). Több olyan tanulmány is megjelent, amely bizonyítja, hogy az eltérő kromoszómális szegmensek eltérő időpontokban replikálódnak a sejtciklus S fázisa során (86). Ezen eredmények miatt a leginkább tanulmányozott kromoszómális régió az emlőskromoszómák későn replikálódó, pericentrikus heterokromatinja lett $(\mathbf{8 7}, \mathbf{8 8}, \mathbf{8 9}, \mathbf{9 0 , 9 1 )}$. Így a megakromoszóma lehetőséget adott - homogén heterokromatikus szerkezetének köszönhetően - a replikáció iniciációs pontjainak felderítésére. Ehhez 5-BrdU inkorporációt vizsgáltak immunfluoreszcens kísérletekben, illetve in situ hibridizációt végeztek. Bebizonyosodott, hogy az egérkromoszómák centromerikus régiójában úgynevezett megareplikátorok vannak, melyek a centromerikus heterokromatin replikációjáért felelősek, illetve fontos szerepet játszanak a kromoszómák de novo képződéséhez szükséges amplifikációban. Az amplikonok határán beépült „idegen” DNS-ek helyével kolokalizációt mutattak a replikáció elsődleges iniciációs helyei. Ugyanazon időpontban hasonló szignált figyeltek meg az „idegen” DNS beépülési helyeitől mentes egérkromoszómák pericentrikus heterokromatinjában is. Ez azt jelenti, hogy az amplikonok határain lévő replikációs iniciációs helyek a szatellit DNS blokkokat határoló nem-szatellit régióiban foglalhatnak helyet. Kiderült az is, hogy a megareplikátorok és a másodlagos replikációs kiindulási pontok szigorú időbeli és térbeli szabályozás alatt állnak. A megakromoszómán az első iniciáció valószínűleg a centromerben következik be, majd nem sokkal később az összes megareplikátor aktívvá válik. 
1996-ban még csak annyit tudtak a megareplikátorról, hogy GC-gazdag régió és körülbelül 10 kb távolságra helyezkedik el az integrálódott „idegen” DNS-től a megakromoszómán. Ezek a megareplikátor elemek reprezentálhatják az AT-gazdag szatellit DNS blokkok nem-szatellit határoló DNS régióit (6).

A gerincesekre jellemző (TTAGGG)n telomerikus ismétlődést próbaként alkalmazva kiderült, hogy az újonnan létrejött kromoszóma is tartalmazza a kromoszómák stabilitásáért felelős telomerikus régiót (73). Ez azt jelentette, hogy a transzfekciót követően a telomerikus szekvencia együtt amplifikálódott a humán és a markergén szekvenciákkal, azaz a kromoszómaképződés egy replikációért felelős kromoszóma szakaszba beépült „idegen” DNS által előidézett megsokszorozódás eredménye.

Megemlítendő érdekesség, hogy egy gigantikus méretű, akár 1000 Mb nagyságú mesterséges kromoszómát hordozó sejtvonal életképességében sem tapasztaltak semmiféle változást (5). Még a sejtek generációs időtartama sem változott szignifikánsan.

Az emlős mesterséges kromoszóma története 2000-ben a humán szatellit DNS-alapú mesterséges kromoszóma prototípusának előállításával folytatódott (7). Annak eldöntésére, hogy lehetséges-e humán mesterséges kromoszómát in vivo létrehozni, megpróbáltak humán szatellit DNS-alapú kromoszómát (hSATAC) előállítani egy olyan humán-kínai hörcsög hibrid sejtvonalban (100), amely rDNS-t hordoz a humán kromoszómákon. A hSATAC-ot - az egér mesterséges kromoszómához hasonlóan - a humán akrocentrikus kromoszómák rövid kar régiójában bekövetkező indukált, nagyléptékű amplifikációval hozták létre. A humán akrocentrikus kromoszómák rövid karjain specifikus kromoszómális régiók (NOR) találhatóak, amelyek jól jellemzett DNS szekvenciákból állnak. Ezek az endogén szekvenciák ideális helynek bizonyultak a humán mesterséges kromoszóma in vivo létrehozásához. Az endogén régiók több előnyt 
hordoztak magukban a humán mesterséges kromoszóma létrehozása szempontjából: 1) a koamplifikált telomerikus szekvenciák múködőképes telomert biztosítanak a de novo létrehozott kromoszómák számára; 2) mivel a centromerikus szatellit DNS-ek nem-kódoló régiók - így hiányzik a transzkripciós „egységük” - ezért megfelelő „feltöltő” helyként szolgálhatnak a hasznos gének számára; 3) a létrehozott hSATAC heterokromatikus természete ellenére az amplifikált rDNS szekvenciák megfelelő kromatin környezetet $(\mathbf{1 0 1}, \mathbf{1 0 2})$ biztosítanak az integrálódott „idegen” gének expressziójához; 4) a humán akrocentrikus kromoszómák rövid karján megtalálható nem-kódoló ismétlődő szekvenciák markerként alkalmazhatók az újonnan képződött kromoszómák jellemzéséhez; 5) illetve tekintettel a hSATAC jövőbeli génterápiás felhasználására, fontos, hogy az rRNS géneken kívül ne legyenek nem kívánt expressziót biztosító gének azokban a kromoszómarégiókban, amelyekben a szükséges amplifikáció végbemegy, hiszen csak így kerülhető el az esetleges fenotipikus hatás. A kísérleti eredmények tehát igazolták, hogy sikerült mitotikusan stabil hSATAC-ot de novo létrehozni, illetve olyan sejtvonalakat előállítani, amelyek hordozzák a hSATAC-ot és akár szubklónozást követően sem veszítik el (7).

Az irodalomból már jól ismerjük, hogy a humán akrocentrikus kromoszómák rövid karjának spontán amplifikációja a leggyakoribb szerkezeti polimorfizmus, fenotipikus hatás nélkül (22). Legjobb példa erre azoknak a gyerekeknek az esete, akiknél az örökölt vagy de novo extra kromoszómák jelenléte - amelyek egy NOR kromoszóma rövid karjából származtak - nem vezettek abnormális fejlődéshez (23). Ezenkívül rendelkezésre áll olyan irodalmi adat is, amelyben egy három generációs család 8 egészséges tagjáról számoltak be, akik szintén akrocentrikus kromoszóma rövid karjából származó számfeletti kromoszómát hordoznak (24). Ezen irodalmi adatok ugyancsak alátámasztják a mesterséges kromoszóma sejtekben történő 
alkalmazásának biztonságosságát.

Az újonnan képződő kromoszómák tehát az élő sejtben történt beavatkozás eredményének tekinthetők. A centromer közeli szakaszok géneket nem hordozó, ismétlődő, úgynevezett szatellit DNS szakaszokból épülnek fel, ezért az újonnan képződött kromoszómák alapanyaga is főként szatellit DNS (SATAC) (3. ábra).
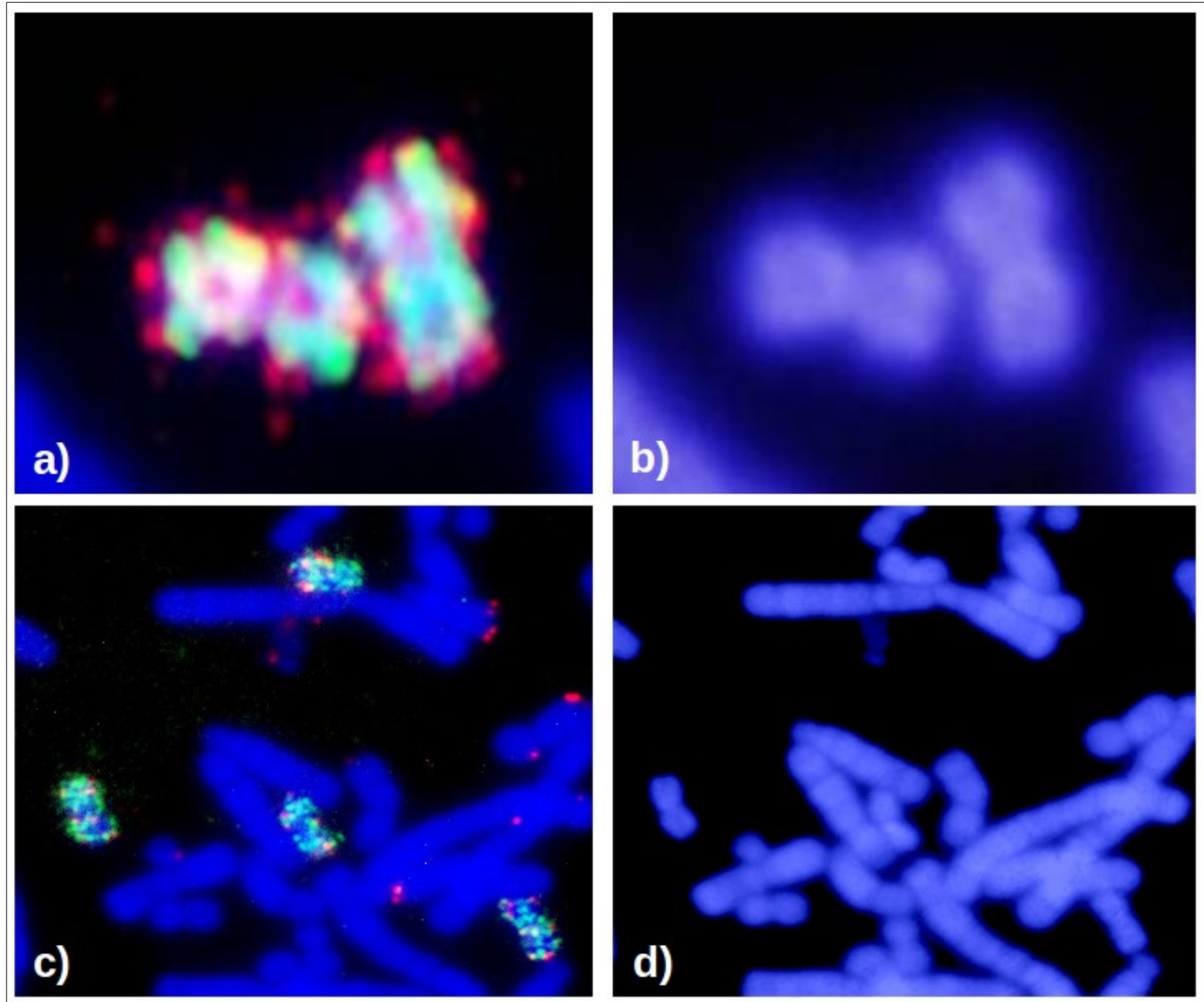

3. ábra. A Platform ACE struktúrája a K2-26-D5 kínai hörcsög petefészek sejtvonalban. a) zöld jel: mouse major szatellit szekvencia, piros jel: puromycin szelekciós markergén, amely a mesterséges kromoszómára épített „idegen” DNS-t jelöli; b) DAPI festés; c) zöld jel: puromycin szelekciós markergén, piros jel: riboszómális DNS, amely a mesterséges kromoszóma kialakulása során bekövetkezett amplifikációra utal; d) DAPI festés. 
Mivel főként ismétlődő, azonos bázissorrendű szakaszokból épülnek fel, nagy mértékben eltérnek a természetes kromoszómáktól. A viszonylag egyszerű felépítés és genetikai tartalom alapján joggal nevezhetők mesterségesnek. A stabil fennmaradásukhoz és működésükhöz szükséges telomer szekvenciákat a „természetes” kromoszómáktól „,szerzik” meg (példaként előfordult már az is, hogy a hörcsögsejtbe átvitt egér mesterséges kromoszóma hörcsög telomert hordozott).

Attól a ponttól, hogy szükség lenne alaposabban megismerni az emlőssejtek centromerét, néhány év alatt sikerült eljutni egy olyan genetikai anyag hordozására alkalmas, biztonságos „eszköz” létrehozásához, amely nemcsak biotechnológiai célokra használható, hanem a génterápiában is kulcsfontosságú lehet.

\subsection{Példák az emlős mesterséges kromoszóma rendszer alkalmazására}

A génterápia mellett, amelyre ma még csak modell kísérletekben használható, az emlős mesterséges kromoszóma géntechnológiai célokra már ma is maradéktalanul alkalmas. Túlzás nélkül állíthatjuk, hogy a lehetőségek szinte korlátlanok:

- például az állattenyésztés és állategészségügy területén: gazdaságilag fontos mennyiségi és minőségi tulajdonságokat meghatározó gének vihetők be a haszonállatok szervezetébe;

- betegségeknek ellenálló állatfajok hozhatók létre;

- gyógyászati vagy egyéb szempontból fontos peptidek, fehérjék és más makromolekulák „termeltethetők” állatokban; 
- $\quad$ illetve sejttenyészetekben;

• növények esetében is sikeresen alkalmazzák terméshozam növelésére, kártevők elleni védekezésre,stb.

Néhány példa az alkalmazásra - a teljesség igénye nélkül:

- 2004-ben Lindenbaum és munkatársai a mesterséges kromoszómát két lépésben, két különböző konstrukcióval (pBLAS-GFP, pZeo-EPO) és ezzel együtt két eltérő antibiotikum rezisztencia génnel töltötték fel. Az emberi, vérképzést elősegítő eritropoietin (EPO) génjét egérsejtekbe juttatták, majd az EPO termelést meghatározták és a nem-mesterséges kromoszómával létrehozott, EPO-termelő sejtvonalakhoz képest nem tapasztaltak eltérést (63). Annak érdekében, hogy bebizonyítsák a mesterséges kromoszóma gén-alapú sejtterápiában való felhasználásának lehetőségét, az eritropoietint expresszáló sejtvonalat NOD-SCID egerekbe oltották, és azt tapasztalták, hogy a kezelt állatok vörösvértest képzése nagy mértékben megnövekedett a kontroll társaikhoz képest (8).

- Az első olyan kísérletek, amelyekben tisztított SATAC-kal állítottak elő transzgenikus állatokat, nemcsak arról számoltak be, hogy sikerült a mesterséges kromoszómákat egér, illetve szarvasmarha embrióba bevinni $(\mathbf{1 3}, \mathbf{2 1})$, hanem a mesterséges kromoszóma sikeres ivarsejt átviteléről is. A mesterséges kromoszóma transzfer négy generáción keresztül valósult meg, és fenotípus változás nélkül adódott át az utódokba. Ezenkívül sikerült a SATAC-ról termeltetett terápiás fehérje expresszióját szövet-specifikusan is kimutatni transzgenikus állatok tejéből (16).

- A korábbi tanulmányok már bizonyították, hogy emberi kromoszómák, valamint kromoszóma fragmentek egér embrionális őssejtekbe történő bejuttatásával sikerült transzgenikus állatokat 
előállítani $(\mathbf{1 2}, \mathbf{4 8})$. Ugyanezt elvégezték fibroblasztokkal is azért, hogy humán immunglobulint termelő borjakat állítsanak elő $(49,50)$. Christmann L. és munkatársai az ACE rendszer segítségével transzgenikus madarakat hoztak létre, amely lehetővé tette humanizált terapeutikumok előállítását a tojásfehérjében (51). Ezek az eredmények megteremtették a rekombináns fehérjetermeltetés lehetőségét transzgenikus háziállatokban, a mesterséges kromoszóma segítségével.

- 2008-ban Katona Róbert és munkatársai kombinálták az emlős mesterséges kromoszóma technológiát az őssejtekkel és célul tűzték ki a ma még gyógyíthatatlan, humán Krabbe betegség állatmodellben történő gyógyítását (9). Az őssejtek azért tűntek remek célpontnak, mert olyan sejtek, melyek önmegújítási képességgel rendelkeznek, illetve többféle sejttípus létrehozására képesek. Ezen tulajdonságaik miatt kiemelt jelentőséggel bírnak a génterápiában is. A globoid sejt leukodisztrófia - más néven Krabbe betegség - egy autoszómális recesszíven öröklődő betegség, melyet a galaktocerebrozidáz enzim (GALC) deficienciája okoz. A GALC egy lizoszómális enzim, amely lebontja a galaktozilceramidot, ami a mielin és mielin-formáló sejtek glikolipid komponense. A betegség progresszív demielinizációhoz, különböző gliozishoz, valamint a fehérállományban jellegzetes sokmagvú (globoid) sejtek megjelenéséhez vezet. Ezen sejtek tartalmazzák a le nem bontott galaktozilceramidot. A toxikus galaktozilszfingozin (psychosine) akkumulációja miatt pusztulnak el a mielint termelő sejtek, de korábban azt hitték róla, hogy az oligodendrociták apoptózisában vesz részt, illetve a sokmagvú globoid sejtek megjelenéséért felelős (25, 26, 27). A Twitcher egér (twi/twi) a humán Krabbe betegség autentikus modellje, melyet a GALC gén mutációjával hoztak létre, ezenkívül jellemző még rá, hogy a fehérje termelődik, de nem rendelkezik enzimaktivitással. A Twitcher egér leginkább azért volt alkalmas erre a célra, mert a betegség lefolyása nagymértékben hasonlít arra, ami az 
emberben történik $(\mathbf{1 0 3 , 1 0 4 )}$. A twi/twi egerek 20 napos korukig normál fejlődést mutatnak, majd ezt követően lelassul a növekedésük és tipikus neurológiai tüneteket produkálnak, például remegés jelentkezik, illetve a hátsó végtagok gyengesége figyelhető meg. A betegség lefolyása gyors és az egerek ritkán élik meg a 40 napot. Tehát ez az egérmodell nemcsak a betegség tanulmányozása szempontjából fontos, hanem a GALC deficiencia gyógyítására szolgáló stratégiák fejlesztésére is alkalmas. A betegség kezelése a terápiás gén mutáns egérbe történő bevitelével valósulhat meg. Korábban már bebizonyosodott, hogy a csontvelő transzplantáció lassítja a Krabbe betegség lefolyását és megnöveli a recipiens Twitcher egerek élettartamát akár

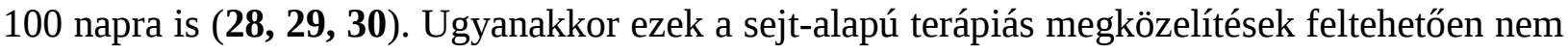
vezetnek eredményre, mivel a keletkező psychosine toxikus a donor sejtekre, ugyanúgy ahogy az endogén sejtekre (31). A megoldást az jelentené, ha a donor sejtekeket rezisztenssé lehetne tenni a keletkező toxinra és nagy mennyiségben expresszálnák a terápiás GALC gént. Az irodalomban közöltek alapján kiderült az is, hogy az őssejtek rezisztensek a psychosine-ra. Ezek az adatok is nagyban hozzájárultak a kombinált emlős mesterséges kromoszóma-őssejt technológia kidolgozásához és alkalmazásához (9).

A kísérletek során olyan pluripotens egér embrionális őssejteket sikerült létrehozni, amelyek a stabilan fenntartott terápiás mesterséges kromoszómáról (tAC) expresszálták a GALC gént. Bebizonyosodott, hogy a létrehozott stabil őssejtvonalak termelték a fehérjét, melynek hiánya a betegek számára végzetes. Ezeket a terápiás őssejteket egér embriókba juttatva bebizonyították, hogy a kiméra twi/twi egerek akár több, mint négyszer hosszabb ideig is éltek a kontroll társaikhoz képest. Ezen génterápiás preklinikai próbálkozás a mesterséges kromoszóma és az őssejtek előnyös tulajdonságait ötvözte, előrevetítve más betegségek gyógyításának lehetőségét (ex vivo génterápia) (9). 
- A mesterséges kromoszóma immortalizált sejtek létrehozására is felhasználható. Az immortalizáció a sejtek korlátlan osztódóképességének elnyerését jelenti. Az őssejtek és a csírasejtek természetesen előforduló, korlátlanul osztódó sejtek. A hámsejtek vagy a fehérvérsejtek esetén spontán immortalizáció is bekövetkezhet. A tumorsejteknél mutációk vagy vírusok vezethetnek immortalizációhoz. A folyamat indukálható, így olyan mesterséges kromoszómát a sejtbe juttatva, amely hordozza az immortalizáló faktort, elvileg bármely sejttípus immortalizálható. Az irodalomi adatok alapján erre a célra a Ras gén (36), a c-Myc onkogén $(34,35)$ vagy akár a telomeráz reverz transzkriptáz (TERT) $(32,33)$ is alkalmas lehet. Az immortalizáló faktorokat termelő sejtvonalak az általuk termelt és esetleg szekretált immortalizáló fehérjével újabb sejtvonalak immortalizálására lehetnek alkalmasak. Az így létrehozott, korlátlanul osztódó sejtek nemcsak rekombináns fehérje előállítására, hanem ellenanyag-, és oltóanyag gyártásra, illetve ipari méretekben különféle hatóanyagok tesztelésére is felhasználhatók.

- A regeneratív medicinában az egyik legígéretesebb terület a károsodott, vagy esetleg elpusztult sejtek őssejtekkel, illetve ezekből származó differenciált sejtekkel történő pótlása. Az őssejtek például származhatnak iPS (induced pluripotent stem cells; iPS) sejtekből is. Ezek azért igényelnek külön figyelmet, mert akár a szervezet saját testi sejtjeiből is előállíthatóak, a visszaprogramozásnak nevezett folyamat során. 2006-ban, a Nobel-díjas Shinya Yamanaka és munkatársai egér fibroblasztokat programoztak vissza és ezzel iPS sejteket állítottak elő (37). A pluripotens állapotba történő visszajuttatáshoz négy transzkripciós faktort - az Oct4-et, Sox2-öt, Klf4-et és a c-Myc-öt - használtak. Egy évvel később már humán indukált pluripotens őssejteket is létrehoztak (38). Az iPS sejtekről bebizonyosodott, hogy mindhárom csírasejtvonal irányba (endoderma, mezoderma, ektoderma) képesek differenciálódni, és az így létrehozott speciális 
sejtek egyaránt felhasználhatóak sejt-, illetve génterápiás célokra (97). Bár a visszaprogramozó faktorok sejtbe történő beviteléhez már több módszert kipróbáltak (vírus-alapú vektorok, mRNS, miRNS, stb.), ezek közül sajnos egyik sem felel meg azoknak a feltételeknek, melyek lehetővé tennék a létrehozott sejtek humán terápiában való alkalmazását. Ennek az a legfőbb oka, hogy a vírus-alapú vektorok magukban hordozzák a random integráció lehetőségét, amely a későbbiekben súlyos következményekhez is vezethet (pl.: tumorképződés). Ezzel ellentétben az emlős mesterséges kromoszóma nem integrálódik a gazdasejt örökítőanyagába, amely lehetővé teszi az iPS sejtek biztonságos előállítását. Az irodalom a legbiztonságosabb visszaprogramozási módszerek közé sorolja a fehérje-alapú kísérleteket. Szerencsére a mesterséges kromoszómát a visszaprogramozó fehérjék termeltetésére is fel lehet használni, így lehetővé válna integrációmentes, biztonságos iPS sejt előállítása. A létrehozott sejtekbe a betegséget okozó hibás gén/gének múködő változatát bejuttatva, a differenciáció segítségével megfelelő, terápiás értékkel bíró sejttípusok állíthatók elő. Ezeket a betegekbe visszajuttatva - elvileg mellékhatások nélküli gyógyulás várható.

- Mesterséges kromoszómát nemcsak állatokban, hanem a növényekben is sikerült már előállítani, ugyancsak kétféle módon: „top down”, illetve indukált „de novo”. A kromoszómák strukturális és funkcionális elemeiről alkotott ismeretek birtokában Preuss D. és munkatársai szintetikus úton közelítették meg a növényi mesterséges kromoszóma előállítását (52). Az Arabidopsis (lúdfü) klónozott telomer szekvenciáját használták fel arra, hogy elvégezzék a kukorica kromoszómáinak telomer-irányított „csonkítását”. Ezzel új lehetőségek nyíltak meg a növényekben történő 'top down' megközelítésre. Irodalmi adatok bizonyítják, hogy sikerült létrehozni olyan platform minikromoszómákat is, amelyek már helyspecifikus rekombinációs kazettát tartalmaztak $(53,54)$. A szakirodalomban közölt adatok alátámasztják az indukált de 
novo növényi kromoszóma létrehozásának sikerességét is, illetve azt, hogy növényi szatellit DNS-alapú mesterséges kromoszómát több növényfajtában (Nicotiana, Brassica) is sikerült már biztonsággal előállítani (55). Ez új távlatokat nyithat a növényi biotechnológiában (pl. terméshozam növelés, kártevők elleni rezisztencia kialakítás, stb.) (14, 15).

Sikertörténet a mesterséges kromoszómával módosított repce (AGRISOMA cég, Kanada), amelyből nagy mennyiségü, és olyan kitűnő minőségű olajat lehet kinyerni, amely alkalmas volt a kanadai hadsereg vadászgépeinek a meghajtására is. 


\section{Célkitűzések}

Bár az emlős mesterséges kromoszóma jelenleg még nem alkalmas humán génterápiára, elmondhatjuk, hogy jelenléte nem toxikus a sejtekre, nem immunogén, nem integrálódik a gazdasejt genomjába, valamint elvileg korlátlan számú és méretű transzgént hordozhat (11). A mesterséges kromoszóma előnyeit az őssejtek pozitív tulajdonságaival ötvözve Katona Róbertnek és munkatársainak korábban már sikerült bizonyítani, hogy a rendszer alkalmas volt a Krabbe betegség állatmodelljének (egér) hatékony kezelésére (9). Ugyanakkor egyre nagyobb az igény a több génhez kötődő - komplex genetikai és daganatos - betegségek gyógyítására alkalmas génbeviteli eszköz kifejlesztésére is. Amennyiben ez megvalósulna, az rendkívül nagy előrelépést jelentene a klinikai alkalmazásokban. Ahhoz, hogy több gén - ezzel együtt több fehérje - egyidejü hibás múködését korrigálni lehessen, olyan génbeviteli rendszerre lenne szükség, amellyel - káros mellékhatások nélkül - több gént egyszerre lehetne bejuttatni. Az emlős mesterséges kromoszóma erre elvileg alkalmas, de problémát jelent, hogy minden új gén kromoszómára töltésekor egy új szelekciós markergént is be kellene juttatnunk a sejtbe, hogy a legutoljára bevitt transzgént hordozó sejtvonalakat is szelektálhassuk. Amellett, hogy véges számú antibiotikum rezisztencia markergén áll rendelkezésre, a nem kívánt expressziójukkal is számolni kell, különös tekintettel a várható mellékhatásokra.

Munkánk során célul tűztük ki, hogy egy olyan ATV plazmidot állítsunk elő, amely alkalmas arra a feladatra, hogy egymás után több ciklusban is töltsünk az ACE kromoszómára hasznos géneket úgy, hogy csak egy szelekciós markergén kazettát használunk a feltöltések során. Ez azt is jelenti, hogy akár az ACE kromoszómán található összes fogadóhelyre is tölthetünk géneket (ez akár 50-200 gén feltöltését is jelentheti). Ezt a vektort szupertöltő vektornak, vagy röviden pST- 
nek neveztük el. A vektor előállítása után célul tűztük ki, hogy két egymást követő ciklusban két különböző gént töltsünk fel az ACE kromoszómára, és így bizonyítsuk be, hogy a pST szupertöltő vektorunk müködik.

Ezért a Platform mesterséges kromoszómát hordozó Y2913D-SFS kínai hörcsög petefészek sejtvonalban két jól nyomon követhető transzgént hordozó plazmid konstrukciót terveztünk a mesterséges kromoszómára tölteni. Az egyik DNS konstrukció az mCherry fehérjét kódoló gént, míg a másik a béta-galaktozidáz enzim génjét (LacZ) hordozza. A transzfekciókat mindkét esetben az ACE ingerázt expresszáló plazmiddal együtt kívántuk elvégezni, míg a helyesen beépülő szupertöltő vektorok meglétét G418-szelekcióval szerettük volna bizonyítani. A helyspecifikus integrációt specifikus primerpárokkal történő polimeráz láncreakcióval terveztük ellenőrizni a kiválasztott sejtklónok genomikus DNS-én. Az mCherry gén jelenléte miatt a piros fluoreszcenciát mutató sejtvonalakat fluoreszcens mikroszkóp használatával kívántuk vizsgálni. A kiválasztott klónokban a transzgén jelenlétét az intakt mesterséges kromoszómán FISH kísérletekkel szándékoztuk kimutatni. Az első feltöltési ciklus végén a szelekciós markergén expressziós kazetta sejtekből történő eltávolítását Cre rekombinázt tranziensen expresszáló plazmid konstrukció sejtbe történő transzfekciójával szerettük volna kivitelezni. A szelekciós markergén kazetta hiányát Ganciklovir szelekcióval szándékoztuk kimutatni. A második feltöltési ciklusban a fent említett ellenőrzési kísérleteken kívül LacZ festéssel is bizonyítani kívántuk a megfelelő sejtklón kiválasztását. 


\section{Anyagok és módszerek}

\subsection{Plazmidok}

A pSEV1R (shuttle expression vector-1R) „entry” vektort (4. ábra/A), a pATVMin ACE targetáló vektort (4. ábra/B), és a pSEV2 (shuttle expression vector-2) „entry” vektort (6. ábra/A) a Chromos Molecular Systems Inc. (jelenleg Calyx Bio-Ventures Inc.) készítette és biztosította számunkra.

A pCre-GFP plazmidot (a plazmid térképét nem tartalmazza a disszertáció) arra használtuk fel, hogy tranziensen expresszáltassuk a Cre rekombinázt. Erre azért volt szükség, hogy eltávolítsuk a LoxP helyekkel határolt neomycin-timidin kináz szelekciós markergén kazettát a mesterséges kromoszómáról (plazmidot Jim Downing laborjából kaptuk ajándékba, St. Jude Children's Research Hospital, Memphis, TN, USA).

A pCXLamIntROK (a plazmid térképét nem tartalmazza a disszertáció) vektor az ACE integráz tranziens expressziójáért felelős, amelynek a segítségével megtörténik a transzgének mesterséges kromoszómára töltése helyspecifikus módon. Ezt a plazmidot is a Chromos Molecular Systems Inc. (jelenleg Calyx Bio-Ventures Inc.) biztosította a számunkra.

A kísérletekhez szükséges, laboratóriumunkban előállított egyéb konstrukciókról az „Eredmények” részben bővebb információ olvasható.

\subsection{A klónozások technikai leírása}

A kísérletekhez használt plazmidokat a Qiagen Midi Kit (Qiagen, 12-145) segítségével 
tisztítottuk a gyártó által mellékelt útmutató szerint. A DNS fragmentek tisztítását a „Molecular cloning: a laboratory manual” című könyvben foglaltak szerint végeztük (127). A molekuláris klónozási lépésekhez DH5 $\alpha$ E. coli kompetens baktériumtörzset (Invitrogen 18265-017), New England Biolabs és Fermentas cégek által forgalmazott restrikciós endonukleázokat és T4 DNS ligázt használtunk, a gyártó ajánlása szerint. A klónozások részletes leírása az Eredmények című fejezetben található.

\subsection{Sejtkultúrák fenntartása}

A Platform mesterséges kromoszómát hordozó Y29-13D-SFS kínai hörcsög ovárium (CHO DG44) sejtvonal a Chromos Molecular Systems Inc.-től származik. Ezt a sejtvonalat MEM alpha médiumban (Gibco, 22571) tenyésztettük, kiegészítve 5\% magzati borjú szérummal (Cansera International Inc., CS-C08-1000-A), 1x streptomycin-penicillin (Gibco, 15070-063), és $10 \mu \mathrm{g} / \mathrm{ml}$ puromycinnel (Sigma, P-7255). Az 1D9-16, RFPG18 és RFPG18-12 sejtvonalakat a fent leírt médiumban tenyésztettük kivéve azt, hogy a puromycint kihagytuk belőle. Az 1D9-16 és az RFPG18-12 sejtvonalak esetén a puromycint 400 g/ml G418-al helyettesítettük (Sigma, G5013), míg az RFPG18 sejtvonal esetében $10 \mu \mathrm{M}$ ganciklovirt használtuk (Sigma, G-2636). Mindegyik sejtvonalat $37^{\circ} \mathrm{C}$-on, $5 \%$-os $\mathrm{CO}_{2}$ koncentráció mellett tenyésztettük.

\subsection{Az emlössejtek transzfekciója}

A plazmidok transzfekcióját Superfect reagens (Qiagen, 301305) alkalmazásával végeztük. A transzfekciót megelőző napon 3×105 sejtet ültettünk ki 6-lyukú sejttenyésztő plate egy lyukába. A transzfekció napján a frissen izolált endotoxin-mentes plazmid DNS-eket TE pufferrel (pH 7.5) $0.2 \mathrm{mg} / \mathrm{ml}$ töménységüre hígítottuk. Eppendorf csőben összekevertünk $1 \mu \mathrm{g}$ ATV vektort és $1 \mu \mathrm{g}$ 
ACE-integrázt expresszáló plazmidot szérum és antibiotikum-mentes sejttenyésztő médiumban, $100 \mu \mathrm{l}$ végtérfogatban. Rövid ideig lecentrifugáltuk. $10 \mu \mathrm{l}$ Superfect transzfekciós reagens hozzáadását követően felszuszpendáltuk az oldatot. Szobahőmérsékleten 10 percig inkubáltuk, hogy kialakulhasson a transzfekciós komplex. Az inkubációs idő alatt eltávolítottuk a transzfekció napján 60-80\%-os konfluenciát mutató - sejtekről a tenyésztő médiumot, majd 2 ml steril, szobahőmérsékletű 1x PBS oldattal (hosphate-buffered saline) megmostuk a sejteket. Az Eppendorf csőben lévő komplexhez 600 l szérumot is tartalmazó médiumot adtunk. A sejteket 2 órán keresztül normál tenyésztési körülmények $\left(37^{\circ} \mathrm{C}, 5 \% \mathrm{CO}_{2}\right)$ között inkubáltuk, miután a komplexet közvetlenül a sejtekhez adtuk. Az inkubációs idő letelte után, eltávolítottuk a komplexet tartalmazó médiumot a sejtekről és 3-szor mostuk steril 1x PBS oldattal őket. A mosások után szérumot is tartalmazó médiumot adtunk a sejtekhez. 24 óra elteltével tripszines kezelés segítségével összegyüjtöttük a sejteket, majd 5 ml tenyésztőmédiumban felszuszpendálva őket, Bürker-kamra segítségével meghatároztuk a sejtszámot. Tápfolyadék segítségével 50 sejt/pl-re hígítottuk a sejtszuszpenziót, majd 96-lyukú plate lyukaiba osztottuk szét úgy, hogy $50 \mu$ l szuszpenzió jusson mindegyik lyukba. 48 órával a transzfekciót követően $150 \mu \mathrm{l}$ - de a 200 l végtérfogatra kiszámolt mennyiségű - antibiotikumot tartalmazó tenyésztő médiumot adtunk a sejtekhez. Amikor a sejtek száma elérte az 50-60-at lyukanként, tripszines kezelést követően 24-lyukú plate egy-egy lyukába passzáltuk őket.

\subsection{Fluoreszcens in situ hibridizáció (FISH)}

A fluoreszcens in situ hibridizációs kísérleteket standard protokoll alapján végeztük (39). A kiválasztott sejtvonalakat a sejtciklus mitózis fázisában 5-6 órás $5 \mu \mathrm{g} / \mathrm{ml}$ kolhicin kezeléssel blokkoltuk. A sejtszuszpenziót $75 \mathrm{mM} \mathrm{KCl}$ oldatban felszuszpendáltuk és ebben tartottuk 10 percig szobahőmérsékleten. A sejteket ezután metanol:ecetsav 3:1 térfogat arányú, -20C-os 
keverékével fixáltuk és 1000 rpm-el 10 percig centrifugáltuk. A fixálót háromszor cseréltük a sejteken, majd a fixált szuszpenzióból tárgylemezre cseppentettünk belőlük. A kicseppentett szuszpenziót fixálóval leöblítettük és sűrített levegővel 3 percig szárítottuk. A kromoszóma készítményeket további felhasználásig (legfeljebb 1-2 napig) sötét dobozban, szobahőmérsékleten tároltuk. Hibridizációs próbának a teljes pPur plazmidot (Clontech, 631601) használtuk, amit FITC fluoreszcens festékkel jelöltünk. A DNS próbákat vagy a Roche DIG Nick Translation Mix-el (1745816), vagy a Roche Biotin Nick Translation Mix-el (1745824) jelöltük. A kromoszóma preparátumokat 1 órán keresztül RNáz-A enzimmel kezeltük $37^{\circ} \mathrm{C}$-on, majd emelkedő koncentrációjú (70\% - 90\% - 100\%) etanol sorban víztelenítettük, két percig $75^{\circ} \mathrm{C}$-on formamiddal denaturáltuk, majd etanol sorral rehidráltuk (100\% - 90\% - 70\% - víz), és utána 12 órán át $37^{\circ} \mathrm{C}$-on a biotin jelölt próbával hibridizáltuk. Mosás után a lekötődött próbát FITC konjugált avidin (Vector A-2011) és biotinilált anti-avidin (Vector BA-0300) ellenanyagokkal jelöltük meg 3 lépcsőben (FITC-jelölt avidin - biotinilált anti-avidin - FITC-jelölt avidin). A kromoszómákat DAPI (4', 6-diamidino- 2-fenilindol, DNS festék) tartalmú oldattal (Vector H1200) fedtük le.

\subsection{Polimeráz láncreakció (PCR)}

A kiválasztott sejtvonalakból genomikus DNS-t izoláltunk a Zymo Research Quick-gDNA MiniPrep (Cat. No.: D3025) kit segítségével. A transzgéneknek a mesterséges kromoszómára történő helyspecifikus integrációját PCR kísérletekkel mutattuk ki a következő primerekkel: 193AF 5'-ACCCCCTTGCGCTAATGCTCTGTTA és NeoR1 5'TCGATGAATCCAGAAAAGCGGCCA. A PCR reakciókat egy MJ Research PTC-150 Minicycler készülékkel hajtottuk végre, 25 l-es reakció-térfogatban. A 25 l-es reakció-térfogat az alábbi összetevőket tartalmazta: 
- kb. 60 ng a sejtvonalakból tisztított gDNS-ből

- $5 \mu \mathrm{ll}$ x Green GoTaq Flexi Buffer (Promega, M891A)

- $\quad$ 2,5 $\mu \mathrm{l}$ 2,5 mM dNTP mix (Fermentas, R0182)

- $2 \mu \mathrm{l}$ (RFPG18 més RFPG18-12 esetén)/ 2,5 $\mu \mathrm{l}$ (1D9-16 esetén) 25 mM MgCl 2 (Promega, A351B)

- $2 \mu \mathrm{l} 10 \mathrm{pmol} / \mu \mathrm{l} 193 \mathrm{AF}$ primer

- $2 \mu \mathrm{ll} 10 \mathrm{pmol} / \mathrm{\mu l} \mathrm{NeoR} 1$ primer

- $\quad$ 0,2 $\mu \mathrm{l}$ GoTaq DNA Polymerase (Promega, M830B)

- 25 l-re kiegészítve steril, tridesztillált vízzel

A reakciót a következő program szerint hajtottuk végre:

- $95^{\circ} \mathrm{C}, 3$ perc (denaturálás)

Majd 40 ciklus az alábbiak szerint:

- $95^{\circ} \mathrm{C}, 30$ másodperc

- $56^{\circ} \mathrm{C}$ (RFPG18 esetén)/ $62^{\circ} \mathrm{C}$ (1D9-16 és RFPG18-12 esetén), 30 másodperc

- $68^{\circ} \mathrm{C}, 1$ perc

Végül $72^{\circ} \mathrm{C}, 10$ perc (a reakció befejezése), utána pedig $4^{\circ} \mathrm{C}$ a minták eltávolításáig.

A várt PCR termék mérete: 784 bp. A keletkező PCR termékeket 1\%-os agaróz-TBE (TRIS borate EDTA) gélen választottuk el 200 ng GeneRuler ${ }^{\mathrm{TM}} 100$ bp DNA Ladder (Fermentas SM0241) molekulaméret jelzőoldat mellett.

\subsection{Mikroszkópia}

A mikroszkópos képeket Zeiss AxioImager.Z1 fluoreszcens mikroszkópon 630x immerziós nagyítással EC Plan-Apochromat 63x/1.4 Oil (Zeiss 420792-9900) objektívvel és 49-es jelü kék (Zeiss 488049-0000) (gerjesztés: G 365 nm, emisszió: BP 445/50 nm) valamint 38 HE jelü zöld (Zeiss 488038-0000) (gerjesztés: BP 470/40 nm, emisszió: BP 525/50), illetve 20-as jelú piros 
(488020-0000) (gerjesztés: BP 546/12 nm, emisszió: BP 575 - 640 nm) szűrőkkel készítettük. A képeket Zeiss Axiovision 4.6 szoftverrel dolgoztuk fel.

\subsection{Béta-galaktozidáz enzim kimutatása sejttenyészetekben}

Az enzim aktivitásának kimutatásához a sejteket 1x PBS oldattal mostuk. A sejteket 2\% formaldehidet és 0,2\% glutáraldehidet tartalmazó 1x PBS oldattal fixáltuk 5 percig, $4^{\circ} \mathrm{C}$-on. Ezt követően ismét 1x PBS mosás következett, majd 1 mg/ml X-gal, 5 mM K-ferricianid, 5 mM Kferrocianid és $2 \mathrm{mM} \mathrm{MgCl}_{2}$ összetételü oldattal festettük a sejteket 14-18 órán keresztül, $37^{\circ} \mathrm{C}$ on. A fölösleges festéket 1x PBS-sel kimostuk és fénymikroszkóp segítségével ellenőriztük a béta-galaktozidáz enzim aktivitását. 


\section{Eredmények}

\subsection{Egy szelekciós markergén kazettát hordozó vektor létrehozása}

Munkánk során sikerült egy olyan új vektort kifejlesztenünk, amely csak egyetlen szelekciós markergén kazettát használ a hasznos gének bevitele során. A rendszer, amelyet továbbfejlesztettünk, egy „entry” plazmidból és egy ACE targeting vektorból (ATV) áll. A

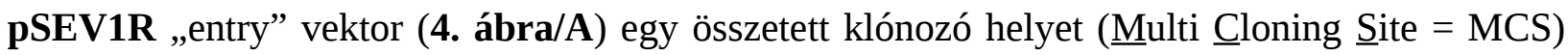
hordoz, amely alkalmas a hasznos gén befogadására. Ez az MCS régió egy olyan expressziós kazetta része, amely egy CMVIE-csirke béta-aktin-béta-globin hibrid (röviden: CX) promótert (125, 126) és egy SV40 polyA szignált is tartalmaz. Az említett expressziós kazettát a továbbklónozás elősegítése érdekében az I-Ceu és PI-PspI élesztő homing endonukleázok hasítóhelyei határolják. A teljes expressziós kazettát - a hasznos génnel együtt - ennek a két enzimnek a segítségével tovább lehet vinni ebből a plazmidból a mesterséges kromoszómát targetáló ATV vektorokba, hiszen azok is tartalmazzák az előbb említett enzimek felismerőhelyeit.

A 4. ábra/B részén a pATVMin plazmid látható, amely a mesterséges kromoszómát targetáló vektorok közé tartozik. A plazmidon feltüntetett I-Ceu és PI-PspI restrikciós hasítóhelyek a hasznos gént tartalmazó expressziós kazetta továbbklónozásához szükségesek. Az attB hely az ACE integráz felismerési helyéül szolgál. Mint azt már a bevezetésben említettem, ez az enzim képes elvégezni a helyspecifikus rekombinációt a mesterséges kromoszómán lévő attP és a targetáló vektoron lévő attB helyek között. A rekombinációt követően a hasznos gént hordozó pATVMin plazmid képes a mesterséges kromoszómára integrálódni. Az integrációt követően a promóter nélküli neomycin rezisztencia gén - amelyet a targetáló vektor tartalmaz - „megszerzi” 
a mesterséges kromoszómán lévő puromycin gén SV40 promóterét. Ez lehetővé teszi olyan G418-rezisztens sejtvonalak izolálását, amelyek a mesterséges kromoszómán hordozzák és arról expresszálják a hasznos vagy terápiás gént.

A munkánk során célul kitűzött szupertöltő vagy röviden pST plazmidot (4. ábra/D) a pATVMin plazmidból (4. ábra/B) állítottuk elő úgy, hogy a pATVMin plazmidot BamHI restrikciós endonukleázzal hasítottuk. Ez a hasítóhely a neomicin antibiotikum rezisztencia gén (NeoR CDS) transzlációs startpontjától 5' irányban található. Túlnyúló BglII restrikciós helyekkel rendelkező, LoxP szekvenciát tartalmazó oligonukleotidokat szintetizáltunk (LoxpBGF: 5’-GATCTataacttcgtataatgtatgctatacgaagttatA, LoxPBGR: 5’GATCTataacttcgtatagcatacattatacgaagttatA). Ezen egyszálú primerekből dupla szálú oligonukleotidokat állítottunk elő, standard módszer alapján. A dupla szálú LoxP oligonukleotidot a pATVMin plazmid BamHI helyére ligáltuk. A LoxP hely megfelelő orientációját DNS szekvenálással ellenőriztük. A pmCCKO14 plazmidot korábban állítottuk elő (4. ábra/C, még nem publikált eredmény). Ez a vektor hordozza a HSV-TK expressziós kazettát, amely egy LoxP helyet is hordoz a polyA szignáltól 3' irányban. A timidin kináz kazetta MC1 promóterrel és egy HSVTK poliadenilációs szignállal van ellátva. A LoxP helyet hordozó pATVMin plazmidot XbaI restrikciós enzimmel hasítottuk, ami egy 3251 bp méretű linearizált DNS-t eredményezett. A timidin kináz expressziós kazettát - a LoxP hellyel együtt - egy XbaISpeI fragmentként izoláltuk a pmCCKO14 plazmidból. A 3141 bp méretű fragmentet beépítettük a LoxP helyet tartalmazó, XbaI enzim-hasított pATVMin vektorba. A keletkezett plazmidot szekvenálással ellenőriztük. A helyes szekvenciával rendelkező plazmidot szupertöltő vektornak vagy röviden pST-nek (4. ábra/D) neveztük el. A létrehozott 6392 bp méretű pST vektor egy promóter nélküli neomycin rezisztencia gént hordoz, amely az ACE integráz felismerő helyétől (attB) 3' irányban helyezkedik el. 


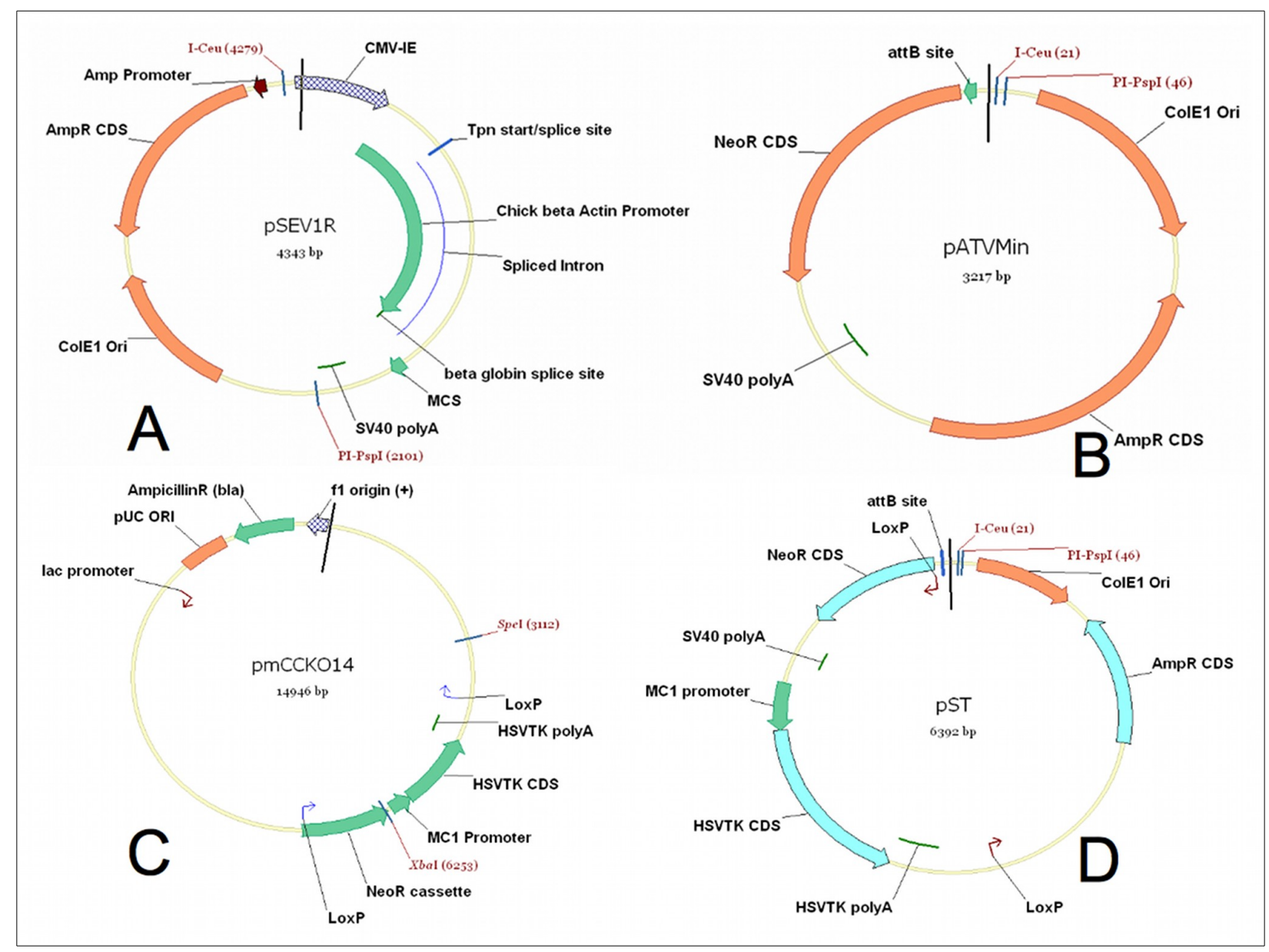

4. ábra. A pSEV1R (A), pATVMin (B), a pmCCKO14 (C) és a pST (D) plazmidok térképe

A konstrukciót úgy készítettük el, hogy a NeoR és timidin kináz szelekciós markergén kazettát határoló LoxP helyek azonos irányultságúak. Ezeket a helyeket azért alkalmaztuk, mert a Cre enzim képes rekombinációt katalizálni a két LoxP hely között és ennek eredményeképpen az egész szelekciós markergén kazetta eltávolítható. Ezt követően a Ganciklovir szelekció lehetővé teszi azoknak a sejtvonalaknak a kiválasztását, amelyekben már nincs jelen a szelekciós markergén kazetta. Ezt a jelenséget sikerrel használtuk fel a génfeltöltő rendszerünkben. A mesterséges kromoszómára töltésnek ezt a módszerét szupertöltő ciklusnak hívjuk, és a folyamatot a 5. ábra foglalja össze. 


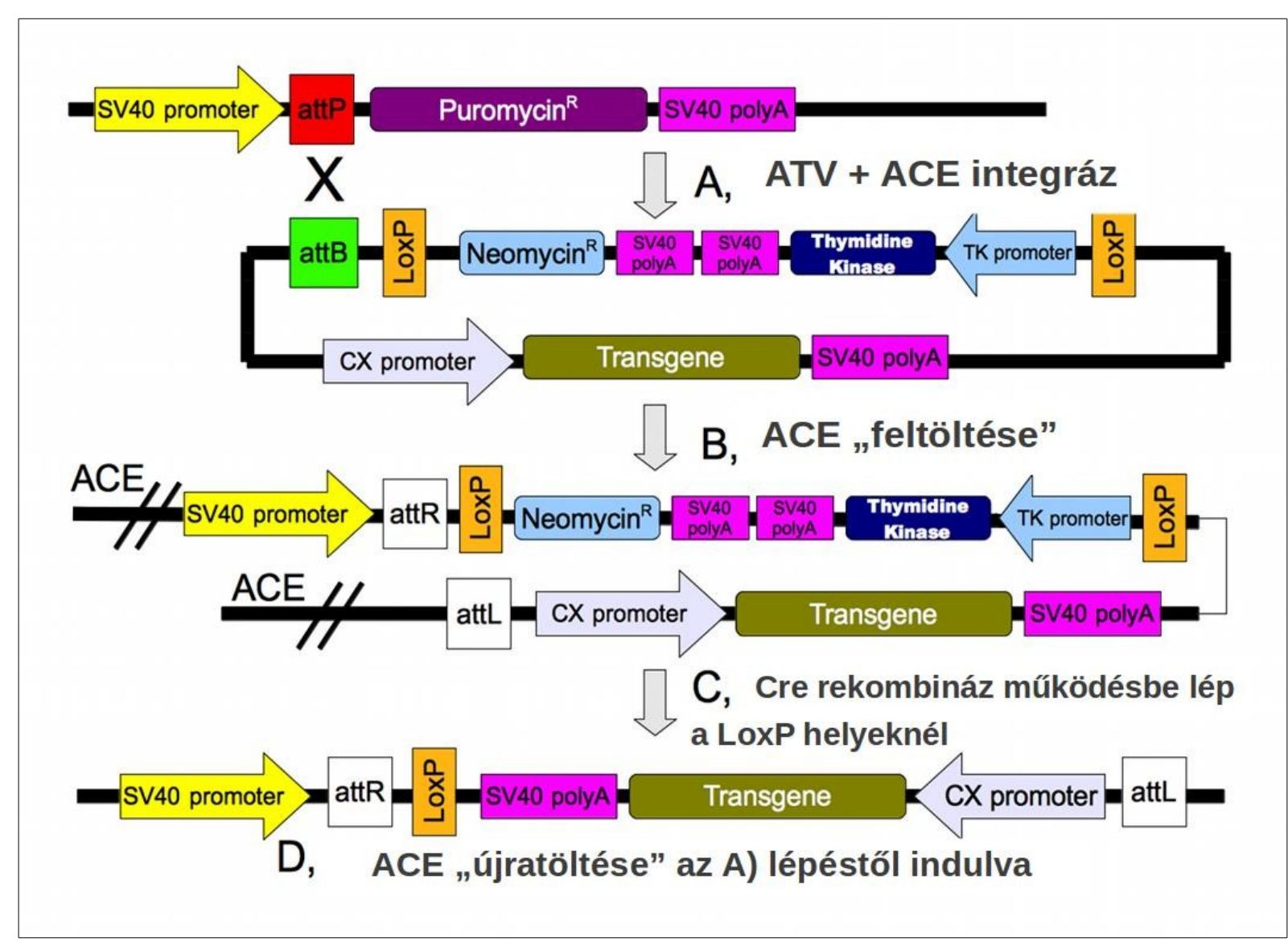

5. ábra. A mesterséges kromoszóma (ACE) „szupertöltő” ciklusa. A) Az ACE integráz által katalizált kromoszómára történő integráció; B) Transzgénnel „feltöltött” mesterséges kromoszóma; C) A neomycin-timidin kináz szelekciós markergén kazetta eltávolítása Cre rekombináz által; D) A mesterséges kromoszóma „újratölthető” állapotba kerül.

A hasznos gént hordozó pST konstrukciók már alkalmasak a mesterséges kromoszómára történő töltéshez.

\subsection{A szupertöltési kísérletekhez szükséges plazmid konstrukciók előállítása és ellenőrzése}

A pSTRFP plazmidot (6. ábra/C) úgy állítottuk elő, hogy a pRSET-B-mCherry plazmidot BamHI és HindIII restrikciós endonukleázokkal hasítottuk és az mCherry kódoló szekvenciáját (a plazmid konstrukcióban röviden RFP-nek nevezve) tartalmazó, 724 bp méretű DNS 
fragmentet izoláltuk. A pSEV2 entry vektort (6. ábra/A) ezzel egy időben BamHI és HindIII restrikciós enzimekkel hasítottuk. A 4501 bp méretű plazmid DNS fragmentet izoláltuk és az RFP kódoló szekvenciát ezzel a fragmenttel ligáltuk. Ennek eredményeként hoztuk létre a pS2RFP plazmidot (6. ábra/B). A 3015 bp méretű RFP expressziós kazettát I-Ceu és PI-PspI élesztő homing endonukleázok segítségével eltávolítottuk, majd a pST vektorba (4. ábra/D) ligáltuk - melyet előtte szintén ugyanezekkel az enzimekkel hasítottunk - és a keletkezett konstrukciót pSTRFP-nek neveztük el (6. ábra/C).

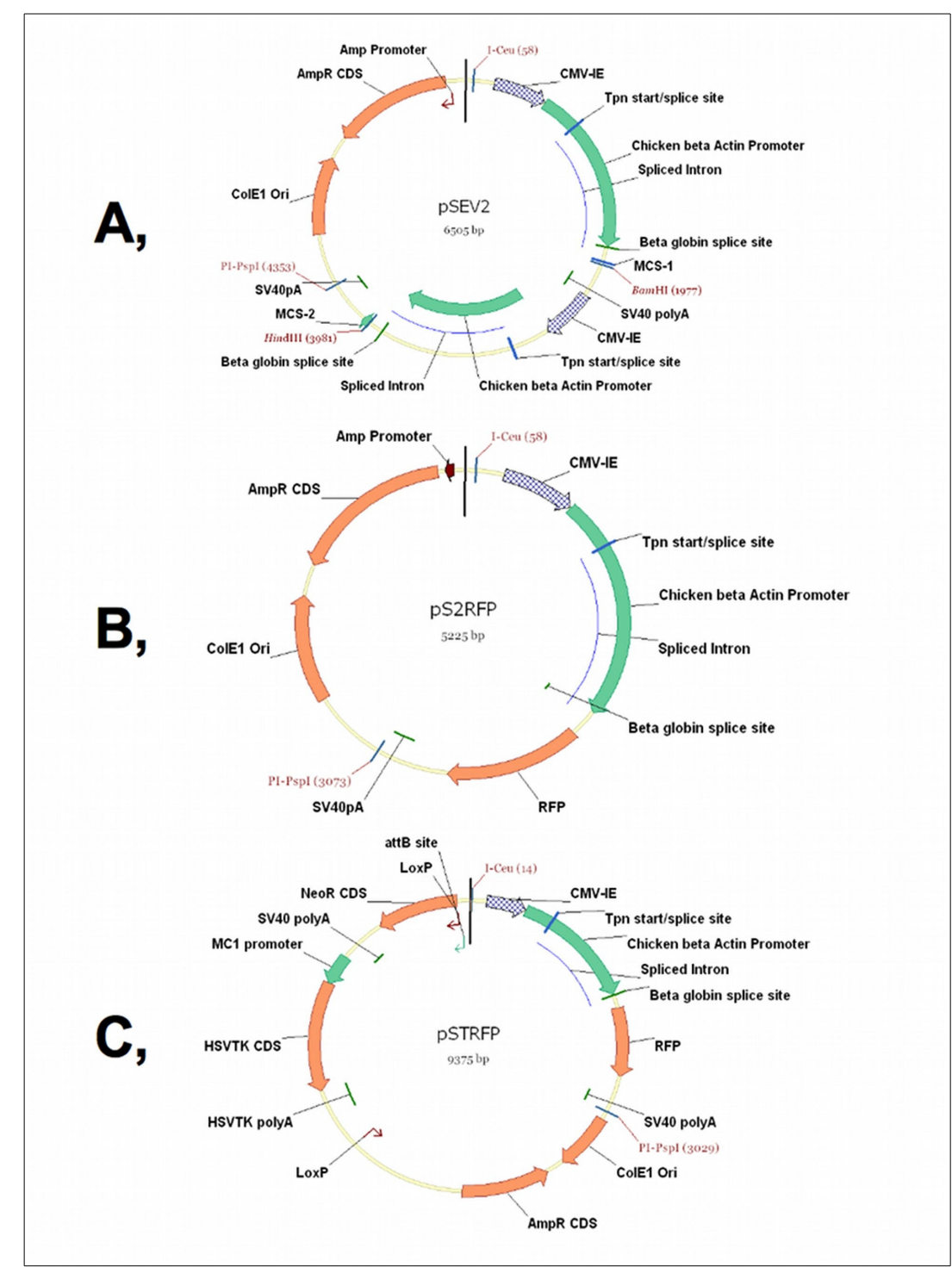

6. ábra. A pSEV2 (A), pS2RFP (B), a pSTRFP (C) plazmidok térképe 
A pSLZ (7. ábra/A) plazmidot úgy készítettük el, hogy a béta-galaktozidáz gén (pCH110 plazmid, Amersham) kódoló szekvenciáját a pSEV1R vektorba (4. ábra/A) klónoztuk. Ehhez a pCH110 plazmidot BamHI és HindIII restrikciós enzimekkel hasítottuk, majd az így keletkezett LacZ-LacY-tartalmú, 3735 bp méretü DNS fragmentet izoláltuk. A pSEV1R plazmidot BglII és HindIII restrikciós enzimekkel hasítottuk. A 4320 bp méretű DNS fragmentet izoláltuk és a LacZ-LacY fragmentet a hasított vektorba ligáltuk. A keletkező 8055 bp méretű plazmidot pSLZ-nek neveztük el (7. ábra/A).

Ezt követően az 5877 bp méretű LacZ-LacY expressziós kazettát I-Ceu és PI-PspI élesztő homing endonukleázok segítségével eltávolítottuk a pSLZ plazmidból (7. ábra/A). Ezek után az említett régiót a 6367 bp méretű pST vektorba ligáltuk, melyet előzőleg ugyanezekkel az enzimekkel hasítottunk, és így létrehoztuk a 12244 bp méretű pSTLZ plazmid konstrukciót (7. ábra/B). 


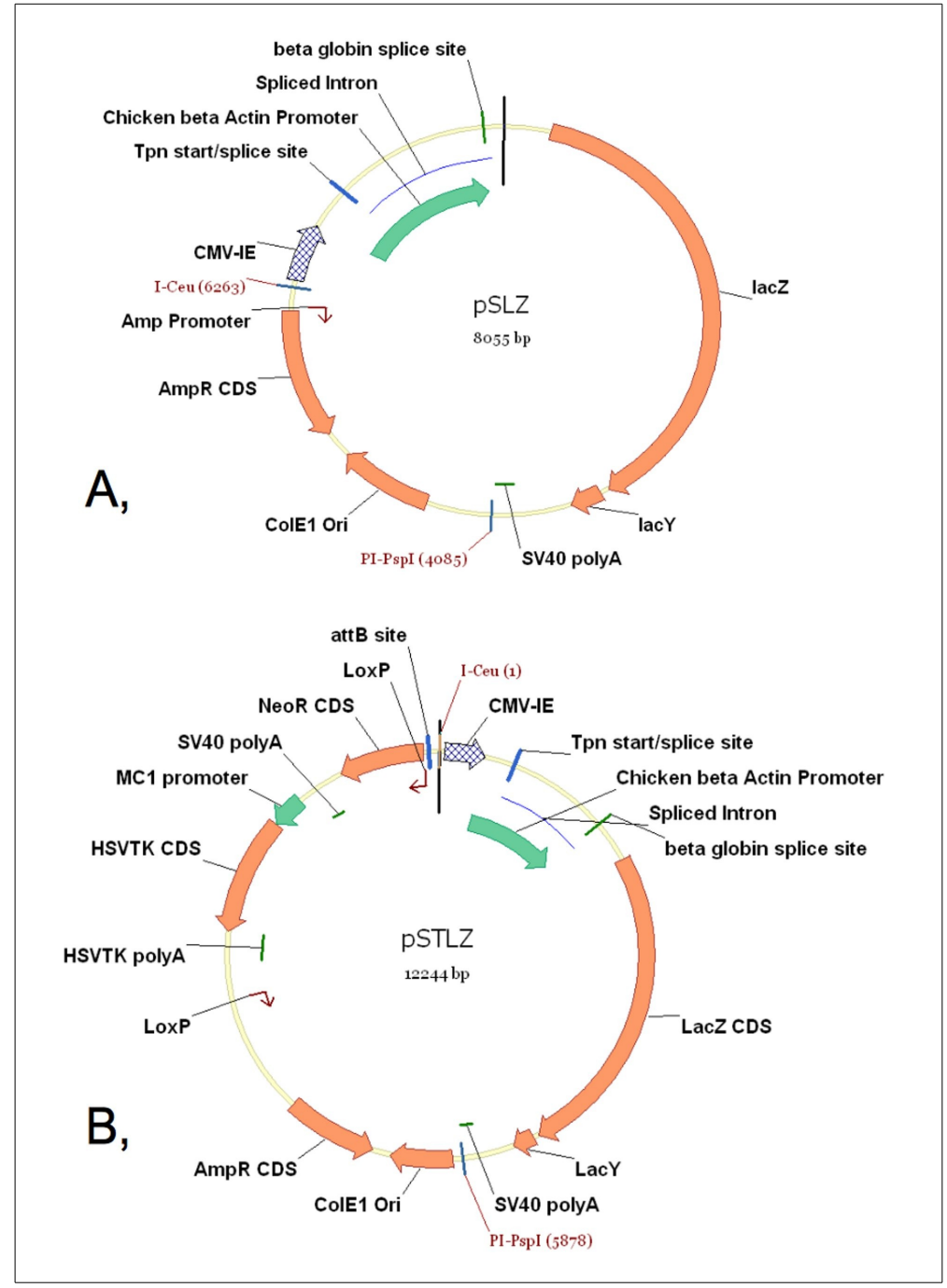

7. ábra. A) pSLZ B) pSTLZ plazmidok térképe

\subsection{A szupertöltő ciklus 1. lépése: mCherry fehérjét a mesterséges kromoszómáról expresszáló sejtvonal létrehozása}

Az 4.2 fejezetben leírtak alapján előállított pSTRFP plazmidot (6. ábra/C) egy Platform mesterséges kromoszómát hordozó sejtvonalba (Y29-13D-SFS) transzfektáltuk, az ACE integrázt expresszáló vektorral (pCXLaminIntROK) együtt. 24 órával később G418 szelekciót indítottunk annak érdekében, hogy olyan kolóniákat növesszünk fel, melyek a mesterséges kromoszómára megfelelően beépülve hordozzák a transzgént tartalmazó szupertöltő vektort. A szelekció 68 stabil transzfektáns sejtvonalat eredményezett. A G418-rezisztens klónokból gDNS- 
t izoláltunk, majd PCR kísérletekkel azonosítottuk az mCherry gént hordozó plazmid helyspecifikus integrációját.

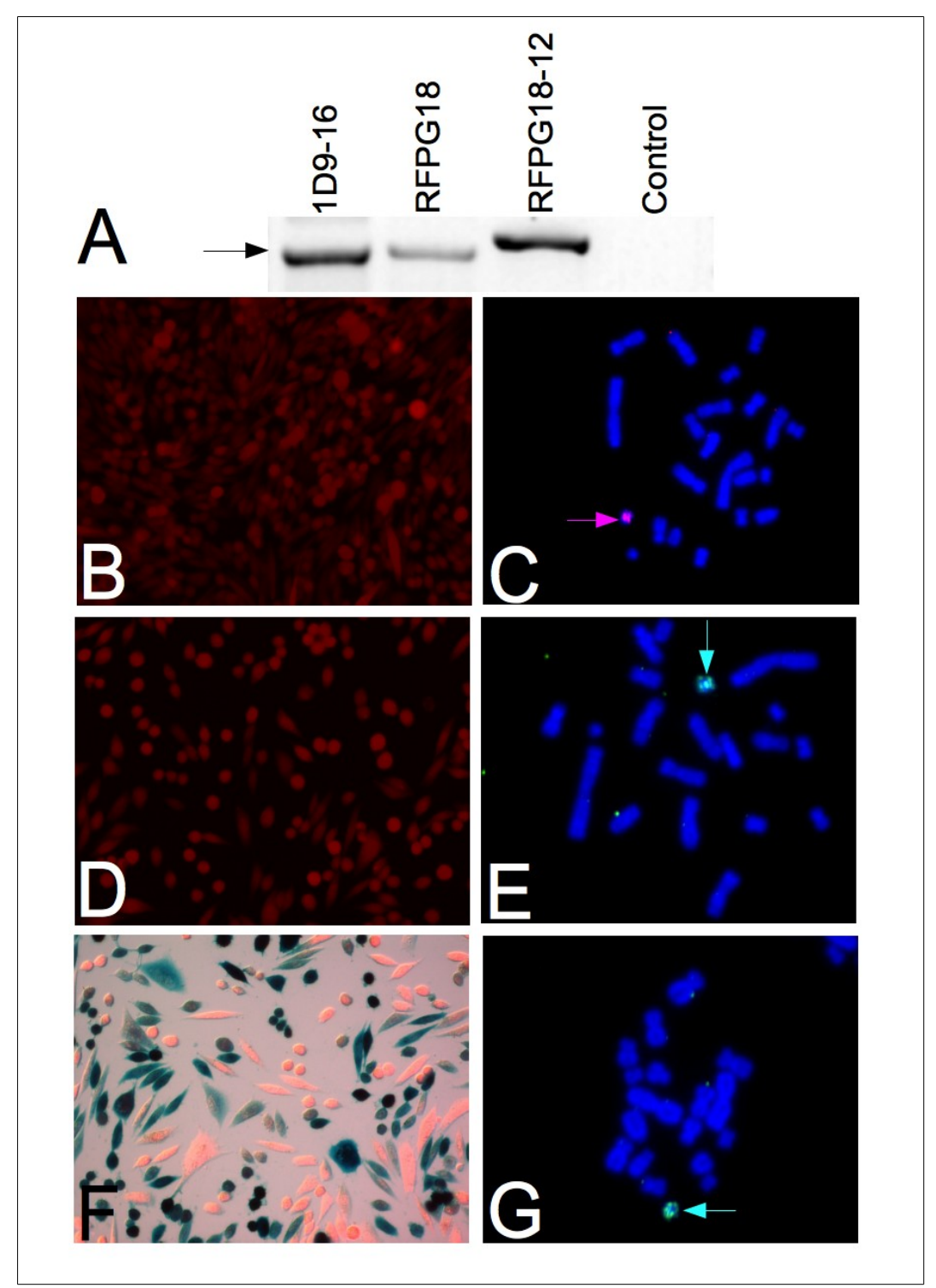

8. ábra. A) Transzgének helyspecifikus integrációjának bizonyítása PCR kísérlettel az 1D9-16, RFPG18 és RFPG18-12 sejtvonalak gDNS-én; B) mCherry fehérje expresszió kimutatása az 1D9-16 sejtvonalban; C) mCherry génnel „feltöltött” mesterséges kromoszóma jelenlétének bizonyítása az 1D9-16 sejtvonalban FISH kísérlettel; D) mCherry fehérjét expresszáló RFPG18 sejtvonal; E) mCherry génnel „feltöltött” mesterséges kromoszóma jelenlétének bizonyítása az RFPG18 sejtvonalban FISH segítségével; F) Piros fluoreszcenciát mutató és LacZ festésre pozitív RFPG18-12 sejtek; G) mCherry és béta-galaktozidáz génnel „feltöltött” kromoszóma jelenlétének bizonyítása az RFPG18-12 sejtvonalban FISH kísérlettel. 
A sejtvonalakat ezenkívül fluoreszcens mikroszkóppal is megvizsgáltuk, amit az mCherry fehérje jelenléte tett lehetővé számunkra. FISH kísérleteket végeztünk azért, hogy kimutassuk a transzgénünket az intakt mesterséges kromoszómán. A kiindulási 68 sejtvonalból, 25 esetén pozitív RFP jelet, illetve random integráció nélküli kromoszómára történő beépülést tapasztaltunk (36\%). A további kísérletekhez az 1D9-16 sejtvonalat választottuk ki, mivel a konstrukció helyesen integrálódott a mesterséges kromoszómára (8. ábra/A), erős piros fluoreszcens jelet mutatott (8. ábra/B) és jó méretű, intakt mesterséges kromoszómával rendelkezett (8. ábra/C: rózsaszín jel).

\subsection{A szelekciós markergén kazetta eltávolítása Cre rekombináz segítségével}

A ganciklovir - amely egy 2'-deoxi-guanozin analóg - először a pSTRFP vektorral bejuttatott timidin-kináznak köszönhetően foszforilálódik és deoxi-guanozin trifoszfát (dGTP) analóggá alakul. A foszforilált állapota miatt a DNS polimeráz nem képes beépíteni, ezért a DNS replikáció leáll, majd a folyamat sejthalállal végződik. Célunk eléréséhez csak olyan sejtvonalakat használhattunk, amelyek rezisztensek a ganciklovir kezelésre valamint szenzitívek a G418 szelekcióra, hiszen ezek nem tartalmazták a szelekciós markergén kazettát. A megfelelő transzfektáns vonalak kiválasztásához meghatároztuk a legalacsonyabb hatékony ganciklovir koncentrációt, amely elegendő volt az 1D9-16 sejtek elpusztításához. A 10 M koncentráció elegendőnek bizonyult a sejtek megöléséhez. A következő lépésben a Cre rekombinázt expresszáló plazmidot (pCre-GFP) az 1D9-16 sejtbe transzfektáltuk, ami az enzim tranziens kifejeződését biztosította (5. ábra/C). Mivel a neomycin és timidin kináz expressziós kazettát LoxP helyek határolták, azt vártuk, hogy a Cre rekombináz képes lesz eltávolítani ezt a markergén konstrukciót a mesterséges kromoszómáról. Ennek köszönhetően csak a feltöltött hasznos gént kifejező kazetta marad hátra a kromoszómán, ami jelen esetben nem más, mint az 
mCherry expressziós kazetta. A transzfekciót követően 24 órával elkezdtük a ganciklovir szelekciót a sejteken - $10 \mu \mathrm{M}$ koncentrációval - azért, hogy rezisztens sejtvonalakat izolálhassunk. A szelekció eredményeként 48 stabil sejtvonalat vizsgáltunk tovább. A kiválasztott sejtvonalakat a korábban említett módon a helyspecifikus integrációt kimutató PCR kísérletekkel, fluoreszcens mikroszkópiával és FISH kísérletekkel vizsgáltuk meg. A kiindulási 48 sejtvonalból 22 esetén intakt mesterséges kromoszómát és megfelelő RFP fehérje expressziót figyeltünk meg (45\%). A kapott eredmények alapján az RFPG18 sejtvonalat (8. ábra/A, D és E: zöld jel) választottuk ki a további kísérletekhez. Ezzel a szupertöltő ciklus első lépése befejeződött.

\subsection{A szupertöltő ciklus 2. lépése: béta-galaktozidáz gént hordozó plazmid konstrukció mesterséges kromoszómára töltése}

A szelekciós markergén kazetta eltávolítását követően a mesterséges kromoszóma ismét képessé vált egy újabb transzgén befogadására (5. ábra/D). Ezért a korábban már leírt módon létrehozott pSTLZ szupertöltő plazmidot (7. ábra/B) az ACE integrázt expresszáló plazmiddal (pCXLamIntROK) együtt a kiválasztott RFPG18 sejtvonalba transzfektáltuk. Ezzel a lépéssel kezdődött el a második feltöltési ciklus (5. ábra/A, B). A transzfekciót követően G418 rezisztens sejtvonalakat izoláltunk. A szelekciónak köszönhetően 74 stabil sejtvonalat állítottunk elő. A konstrukció helyes kromoszómára épülését ebben az esetben is a helyspecifikus integrációt kimutató PCR kísérletekkel igazoltuk. A szelektált vonalakat a FISH kísérleteken, és a piros fluoreszcenciájukon kívül még az „Anyagok és módszerek” c. fejezetben leírtak alapján LacZ festéssel is teszteltük. A kiindulási 74 stabil transzfektáns sejtvonal közül 37 esetén tapasztaltunk RFP expressziót és pozitív jelet a LacZ festést követően (50\%), míg ezek közül 21 sejtvonalban sikerült random integráció nélküli beépülést kimutatnunk (56,7\%). A helyspecifikus integrációt 
kimutató PCR (8. ábra/A), a FISH (8. ábra/G: zöld jel), az RFP jel (8. ábra/F) és a LacZ jel (8. ábra/F) alapján az RFPG18-12 sejtvonal bizonyult a legjobb sejtvonalnak. Ebben a sejtvonalban tehát a pST szupertöltő plazmid segítségével két feltöltő ciklus elvégzésével sikerült két különböző transzgént a mesterséges kromoszómára tölteni és ezzel bizonyítani, hogy a plazmid alkalmas a többszörös feltöltésre. 


\section{Diszkusszió}

Munkánk során célul tûztük ki egy olyan génbeviteli eszköz kidolgozását, amely lehetővé teszi az emlős mesterséges kromoszóma több hasznos génnel történő feltöltését anélkül, hogy mindegyik alkalommal egy újabb szelekciós markergént kellene használni.

Erre azért volt szükség, mert hiába van akár 50-200 fogadóhely az emlős mesterséges kromoszómán, a markergének korlátozott száma határt szabott a feltölthetőségének. Ez fôként akkor okoz(hatna) problémát, ha több gén együttes jelenléte szükséges a sejtekben. Így például több génnel végrehajtott transzgenezis kísérleteknél, bizonyos biokémiai útvonalak tanulmányozásánál, illetve daganatos és komplex betegségek terápiás kezelésekor. Az is probléma lehet néhány szelekciós markergén esetében, hogy bizonyos szervekben vagy szövetekben emelkedett expressziós szintet mutatnak, ami nem kívánt mellékhatásokhoz vezethet.

Munkánk során sikerült előállítanunk a célkitúzésben megfogalmazott szupertöltő plazmidot, amelyet azután sikeresen alkalmaztunk két különböző hasznos gén mesterséges kromoszómára töltésére. A feltöltések eredményeként sikeresen előállított sejtvonalak intakt mesterséges kromoszómát hordoztak, amelyek funkcionálisan expresszálták mind az mCherry, mind a LacZ gént. Kimutattuk, hogy az említett konstrukciók helyesen integrálódtak a mesterséges kromoszómára (8. ábra). Bebizonyítottuk, hogy egyetlen szelekciós markergén kazetta is elegendő ahhoz, hogy két különböző hasznos gént a mesterséges kromoszómára töltsünk. A kísérletek során igazoltuk, hogy a mesterséges kromoszóma több hasznos génnel történő feltöltése viszonylag könnyen kivitelezhető, hatékony, és nem jelent különösebb toxicitást a sejtekre nézve. A kísérleti eredmények tovább erősítik az elméletileg már bizonyított tényt, hogy 
a mesterséges kromoszóma a szupertöltő vektor használatával kombinálva alkalmas lehet komplex, több gén vizsgálatát együttesen érintő alapkutatási kísérletek elvégzésére, több gént is hordozó transzgénikus állatok és növények létrehozására, illetve olyan terápiás célokra, amikor több gén bevitele szükséges a betegség kezeléséhez. Ezenkívül, amennyiben szükséges, a mesterséges kromoszóma - előzetes tisztítást követően - akár mikrosejt fúzióval, akár transzfekciós reagenssel, illetve mikroinjektálással átvihető egyik sejtből a másikba (128).

A szupertöltő vektor használata során az is bebizonyosodott, hogy a szelekciós markergének maradéktalanul eltávolíthatók a sejtekből, így nem okoznak nem kívánt mellékhatásokat a szervezetben. Ezzel teljesült az a nem titkolt célkitűzésünk is, hogy biztonságosabbá tegyük a mesterséges kromoszóma génterápiás használatát.

A kísérletekhez szükséges plazmidokat, illetve sejtvonalakat az SF/548-25/2013 határozattal engedélyezett géntechnológiai módosítást végző létesítmény laboratóriumában állítottuk elő. 


\section{Köszönetnyilvánítás}

Köszönöm témavezetőmnek, Dr. Katona Róbertnek, amiért lehetőséget adott arra, hogy a doktori dolgozatomat csoportjában készíthessem el. Széleskörű szakmai tudásával mindvégig segítette munkámat. Az elmúlt néhány év során bármikor számíthattam rá szakmai kérdésekben.

Köszönettel tartozom Prof. Dr. Hadlaczky Gyulának, aki nagyban hozzájárult ahhoz, hogy a csoportban dolgozhassak. Mindvégig türelemmel, jobbító kritikával és tanácsokkal segítette a munkámat.

Hálás vagyok Dr. Cserpán Imrének, amiért a szakdolgozatom elkészítéséhez szükséges évek alatt megismertette velem a molekuláris biológia alapjait.

Doktori munkámat figyelemmel kísérte és hasznos tanácsokkal segítette Prof. Dr. Udvardy Andor is. Köszönöm doktori munkámhoz való lelkiismeretes hozzáállását, türelmét.

Hálával tartozom csoportunk jelenlegi és volt munkatársainak, Dr. Blazsó Péter Gábornak, Dr. Csonka Erikának, Dr. Fodor Katalinnak, Dr. Praznovszky Tündének és Dr. Tubak Vilmosnak, akikhez bármikor fordulhattam segítségért akár szakmai, akár nem szakmai problémákkal kapcsolatban.

Köszönettel tartozom még a csoportunk többi tagjának, így Deák Máriának, Horváth Csillának, Katonáné Székely-Szűcs Kingának, Kereső Juditnak, Kovács Tímeának, Mózesné Holló Gyöngyinek, Odrovics Balázsnak és Rózsavölgyi Mártának. Segítségük nagyban hozzájárult a kísérletek sikerességéhez. 
Megköszönöm az MTA Szegedi Biológiai Központ Genetikai Intézet dolgozóinak, hogy szakmai fejlődésemet elősegítő közegben dolgozhattam.

Köszönet illeti szüleimet, testvéremet és a páromat, hogy bármikor számíthattam a támogatásukra, amely nagyban hozzásegített a munkám elvégzéséhez. 


\section{Irodalomjegyzék}

1. Inder M. Verma and Matthew D. Weitzman GENE THERAPY: Twenty-first century medicine. Annual Review of Biochemistry 74, 711-738 (2005).

2. Seymour, L. W., Fisher, K. D. Preclinical screening of gene therapy in human tissues. Human Gene Therapy 20, 291-292 (2009).

3. Hadlaczky, G. et al. Centromere formation in mouse cells cotransformed with human DNA and a dominant marker gene. Proc. Natl. Acad. Sci. U.S.A. 88, 8106-8110 (1991).

4. Praznovszky, T. et al. De novo chromosome formation in rodent cells. Proc. Natl. Acad. Sci. U.S.A. 88, 11042-11046 (1991).

5. Kereso, J. et al. De novo chromosome formations by large-scale amplification of the centromeric region of mouse chromosomes. Chromosome Res 4, 226-239 (1996).

6. Hollo, G. et al. Evidence for a megareplicon covering megabases of centromeric chromosome segments. Chromosome Res 4, 240-247 (1996).

7. Csonka, E. et al. Novel generation of human satellite DNA-based artificial chromosomes in mammalian cells. J. Cell Sci 113 (Pt 18), 3207-3216 (2000).

8. Lindenbaum, M. et al. A mammalian artificial chromosome engineering system (ACE system) applicable to biopharmaceutical protein production, transgenesis and gene-based cell therapy. Nucleic Acids Res 32, e172 (2004).

9. Katona, R. L. et al. A combined artificial chromosome-stem cell therapy method in a model experiment aimed at the treatment of Krabbe's disease in the Twitcher mouse. Cell. Mol. Life Sci 65, 3830-3838 (2008). 
10. Duncan, A. and Hadlaczky, G. Chromosomal engineering. Curr. Opin. Biotechnol 18, 420-424 (2007).

11. Hadlaczky, G. Satellite DNA-based artificial chromosomes for use in gene therapy. Curr. Opin. Mol. Ther 3, 125-132 (2001).

12. Farr, C. J. et al. Generation of a human X-derived minichromosome using telomereassociated chromosome fragmentation. Embo Journal 14, 5444-5454 (1995).

13. Heller, R., Brown, K. E., Burgtorf, C., Brown, W. R. A. Mini-chromosomes derived from the human Y chromosome by telomere directed chromosome breakage. Proceedings of the National Academy of Sciences of the United States of America 93, 7125-7130 (1996).

14. Noutoshi, Y., Arai, R., Fujie, M., Yamada, T. Designing of plant artificial chromosome (PAC) by using the Chlorella smallest chromosome as a model system. Nucleic Acids Symp Ser 37, 143-144 (1997).

15. Robert, T. Gaeta, Rick, E. Masonbrinck, Lakshminarasimhan, Krishnaswamy, Changzeng Zhao, and James, A. Birchler. Synthetic chromosome platforms in plants. Annual Review of Plant Biology 63, 307-330 (2012).

16. Monteith, D. P., Leung, J. D., Borowski, A. H., Co, D. O., Praznovszky, T., Jirik, F. R., Hadlaczky, G., Perez, C. F. Pronuclear microinjection of purified artificial chromosomes for generation of transgenic mice: pick-and-inject technique. Methods Mol Biol 240, 227$242(2004)$.

17. Saffery, R. et al. Construction of neocentromere-based human minichromosomes by telomere-associated chromosomal truncation. Proceedings of the National Academy of Sciences of the United States of America 98, 5705-5710 (2001).

18. Voe, T. et al. Efficient male and female germline transmission of a human chromosomal 
vector in mice. Genome Res. 11, 124-136 (2001).

19. Wong, L. H., Saffery, R., Choo, K. H. A. Construction of neocentromere-based human minichromosomes for gene delivery and centromere studies. Gene Therapy 9, 724-726 (2002).

20. De Jong, G., Telenius, A. H., Telenius, H., Perez, C. F., Drayer, J. I. and Hadlaczky, Gy. Mammalian artificial chromosome pilot facility: Large-scale isolation of functional satellite DNA-based artificial chromosomes. Cytometry 35, 129-133 (1999).

21. Telenius, H., Pelmear, A. H., Tunnacliffe, A., Carter, N. P., Behmel, A., Ferguson-Smith, M. A., Nordenskjold, M., Pfragner, R. and Ponder, B. A. Cytogenetic analysis by chromosome painting using DOP-PCR amplified flow-sorted chromosomes. Genes Chromosomes Cancer 4, 257-263 (1992).

22. Conte, R. A., Kleyman, S. M., Laundon, C. and Verma, R. S. Characterization of two extreme variants involving the short arm of chromosome 22: are they identical. Ann. Genet. 40, 145-149 (1997).

23. Gravholt, C. H., and Friedrich, U. Molecular cytogenetic study of supernumerary marker chromosomes in an unselected group of children. Am. J. Med. Genet. 13, 106-111 (1995).

24. Fu, S., Fu, H., Xiao, H., Song, X., Chen, J., Gao, C., Qiu, H. and Cheng, Z. Molecular cytogenetic study of an extra small chromosome. Yi Chuan Xue Bao. 19, 294-297 (1992).

25. Suzuki, K. Twenty five years of the „psychosine hypothesis”: A personal perspective of its history and present status. Neurochem. Res. 23, 251-259 (1998).

26. Wenger, D. A., Rafi, M. A., Luzi, P., Datto, J. and Costantino-Ceccarini, E. Krabbe disease: Genetic aspects and progress toward therapy. Mol. Genet. Metab. 70, 1-9 (2000). 
27. Wenger, D. A. Murine, canine and non-human primate models of Krabbe disease. Mol. Med. Today 6, 449-451 (2000).

28. Hoogerbrugge, P. M., Poorthuis, B. J., Wagemaker, G., van Bekkum, D. W. and Suzuki, K. Alleviation of neurologic symptoms after bone marrow transplantation in twitcher mice. Transplant. Proc. 21, 2980-2981 (1989).

29. Hoogerbrugge, P. M., Suzuki, K., Suzuki, K., Poorthuis, B. J., Kobayashi, T., Wagemaker, G. and van Bekkum, D. W. Donor-derived cells in the central nervous system of twitcher mice after bone marrow transplantation. Science 239, 1035-1038 (1988).

30. Hoogerbrugge, P. M., Poorthuis, B. J., Romme, A. E., van de Kamp, J. J., Wagemaker, G. and van Bekkum, D. W. Effect of bone marrow transplantation on enzyme levels and clinical course in the neurologically affected twitcher mouse. J. Clin. Invest. 81, 17901794 (1988).

31. Taylor, R. M., Lee, J. P., Palacino, J. J., Bower, K. A., Li, J., Vanier, M. T., Wenger, D. A., Sidman, R. L. and Snyder, E. Y. Intrinsic resistance of neural stem cells to toxic metabolites may make them well suited for cell non-autonomous disorders: Evidence from a mouse model of Krabbe leukodystrophy. J. Neurochem. 97, 1585-1599 (2006).

32. Hahn, W. C., Meyerson, M. Telomerase activation, cellular immortalization and cancer. Ann. Med. 33, 123-9 (2001).

33. Lü, M. H., Liao, Z. L., Zhao, X. Y., Fan, Y. H., Lin, X. L., Fang, D. C., Guo, H., Yang, S. M. hTERT-based therapy: a universal anticancer approach. Oncol. Rep. 28, 1945-52 (2012).

34. Bartlett, P. F., Reid, H. H., Bailey, K. A., Bernard, O. Immortalization of mouse neural precursor cells by the c-myc oncogene. Proc. Natl. Acad. Sci. 85, 3255-3259 (1988). 
35. Jesus Gil, Preeti Kerai, Matilde Lleonart, et al. Immortalization of primary human prostate epithelial cells by c-Myc. Cancer Res. 65, 2179-2185 (2005).

36. Kelekar, A., Cole, M. D. Immortalization by c-myc, H-ras, and Ela oncogenes induces differential cellular gene expression and growth factor responses. Mol. Cell. Biol. 7, 3899-3907 (1987).

37. Kazutoshi Takahashi, Shinya Yamanaka. Induction of pluripotent stem cells from mouse embryonic and adult fibroblast cultures by defined factors. Cell 126, 663-676 (2006).

38. Kazutoshi Takahashi, Koji Tanabe, Mari Ohnuki, Megumi Narita, Tomoko Ichisaka, Kiichiro Tomoda, Shinya Yamanaka. Induction of pluripotent stem cells from adult human fibroblasts by defined factors. Cell 131, 861-872 (2007).

39. Csonka E. De novo generation of satellite DNA-based artificial chromosomes by induced large-scale amplification. Methods Mol. Biol. 738, 111-125 (2011).

40. David, A. W., Franklin, O. S. Progress in the use of gene transfer methods to treat genetic blood diseases. Human Gene Therapy. 11(15), 2059-2066 (2000).

41. Huibi Cao, Tiago N Machuca, Jonathan C Yeung, Jing Wu, Kai Du, Cathleen Duan, Kohei Hashimoto, Virginia Linacre, Allan L Coates, Kitty Leung, Jian Wang, Herman Yeger, Ernest Cutz, Mingyao Liu, Shaf Keshavjee, Jim Hu. Efficient gene delivery to pig airway epithelia and submucosal glands using helper-dependent adenoviral vectors. Molecular Therapy Nucleic Acids 2, e127 (2013).

42. Baum, C., Düllmann, J., Li, Z., Fehse, B., Meyer, J., Williams, D. A., von Kalle, C. Side effects of retroviral gene transfer into hematopoietic stem cells. Blood. 101(6), 2099-114 (2003).

43. Dong A., Rivella S., Breda L. Gene therapy for hemoglobinopathies: progress and challenges. Transl. Res. 161(4), 293-306 (2013).

44. Cancio, M. I., Reiss, U. M., Nathwani, A. C., Davidoff, A. M., Gray, J. T. Developments 
in the treatment of hemophilia B: focus on emerging gene therapy. Appl. Clin. Genet. 6, 91-101 (2013).

45. Irvine, D. V., Shaw, M. L., Choo, K. H. A., Saffery, R. Engineering chromosomes for delivery of therapeutic genes. Trends Biotechnol. 23, 575-583 (2005).

46. Katoh, M., Ayabe, F., Norikane, S., Okada, T., Masumoto, H., Horike, S., Shirayoshi, Y., Oshimura, M. Construction of a novel human artificial chromosome vector for gene delivery. Biochem Biophys Res Commun 321, 280-290 (2004).

47. Henikoff, S., Furuyama, T. The unconventional structure of centromeric nucleosomes. Chromosoma 121(4), 341-52 (2012).

48. Tomizuka, K., Yoshida, H., Uejima, H., Kugoh, H., Sato, K., Ohguma, A., Hayasaka, M., Hanaoka, K., Oshimura, M., Ishida, I. Functional expression and germline transmission of a human chromosome fragment in chimaeric mice. Nat Genet 16, 133-143 (1997).

49. Kuroiwa, Y., Kasinathan, P., Choi, Y. J., Naeem, R., Tomizuka, K., Sullivan, E. J., Knott, J. G., Duteau, A., Goldsby, R. A., Osborne, B. A. et al. Cloned transchromosomic calves producing human immunoglobulin. Nat Biotechnol 20, 889-894 (2002).

50. Robl, J. M., Kasinathan, P., Sullivan, E., Kuroiwa, Y., Tomizuka, K., Ishida, I. Artficial chromosome vectors and expression of complex proteins in transgenic animals. Theriogenology 59, 107-113 (2003).

51. Christmann, L., Eberhardt, D. M., Leavitt, M. C., Harvey, A. J. Artificial chromosomes and transchromosomic avians. United States Patent 20,06,01,74,364 http://www.freepatentsonline.com/20060174364.html

52. Preuss, D., Copenhaver, G. Plant artificial chromosome compositions and methods. United States Patent 70,15,372 http://www.freepatentsonline.com/7015372.html

53. Yu, W., Lamb, J. C., Han, F., Birchler, J. A. Telomere-associated chromosomal truncation in maize. Proc Natl Acad Sci USA 103, 17331-17336 (2006).

54. Yu, W., Han, F., Gao, Z., Vega, J. M., Birchler, J. A. Construction and behavior of engineered minichromosomes in maize. Proc Natl Acad Sci USA 104, 8924-8929 (2007). 
55. Perez, C., Fabijanski, S., Perkins, E. Plant artificial chromosomes, uses thereof and methods of preparing plant artificial chromosomes. United States Patent 20,06,01,43,732 http://www.freepatentsonline.com/20060143732.html

56. Lange-Gustafson, B.J. and Nash, H.A. Purification and properties of Int-h, a variant protein involved in site-specific recombination of bacteriophage lambda. J Biol Chem 259, 12724-12732 (1984).

57. Christ, N. and Droge, P. Alterations in the directionality of lambda site-specific recombination catalyzed by mutant integrases in vivo. J Mol Biol 288, 825-836 (1999).

58. Lorbach, E., Christ, N., Schwikardi, M. and Droge, P. Site-specific recombination in human cells catalyzed by phage lambda integrase mutants. J Mol Biol 296, 1175-1181 (2000).

59. Christ, N., Corona, T. and Droge, P. Site-specific recombination in eukaryotic cells mediated by mutant $\lambda$ integrases: implications for synaptic complex formation and the reactivity of episomal DNA segments. J Mol Biol 319, 305-314 (2002).

60. Christ, N. and Droge, P. Genetic manipulation of mouse embryonic stem cells by mutant $\lambda$ integrase. Genesis 32, 203-208 (2002).

61. Kozak, M. Point mutations close to the AUG initiator codon affect the efficiency of translation of rat pre-proinsulin in vivo. Nature 308, 241-246 (1984).

62. Kozak, M. Point mutations define a sequence flanking the AUG initiator codon that modulates translation by eukaryotic ribosomes. Cell 44, 283-292 (1986).

63. Egrie, J. The cloning and production of recombinant human erythropoietin. Pharmacotherapy. 10, 3S-8S (1990).

64. Bank, A. Human somatic cell gene therapy. Bioessays 18(12), 999-1007.

65. Hadlaczky, Gy. Structure of metaphase chromosomes of plants Int. Rev. Cytol. 94, 57-76 (1985).

66. Murray, A.W., Szostak, J.W. Construction of artificial chromosomes in yeast. Nature 
(London) 305, 189-193 (1983).

67. Burke, D.T., Carle, G.F., Olson, M.V. Cloning of large segments of exogenous DNA into yeast by means of artificial chromosome vectors. Science 236, 806-812 (1987).

68. Hadlaczky, Gy., Sumner, A. T., Ross, A. Protein-depleted chromosomes. II. Experiments concerning the reality of chromosome scaffolds. Chromosoma 81, 557-567 (1981).

69. Maniatis, T., Hardison, R. C., Lacy, E., Lauer, J., O'Connell, C., Quon, D., Sim, D. K., Efstratiadis, A. The isolation of structural genes from libraries of eucaryotic DNA. Cell 15, 687-701 (1978).

70. Harper, M. E., Saunders, G. F. Localization of single copy DNA sequences of G-banded human chromosomes by in situ hybridization. 83, 431-439 (1981).

71. Therman, E., Sarto, G. E., Patau, K. Apparently isodicentric but functionally monocentric X chromosome in man. Am. J. Hum. Genet. 26, 83-92 (1974).

72. Meyne, J., Ratliff, R. L., Moyzis, R. K. Conservation of the human telomere sequence (TTAGGG) $)_{\mathrm{n}}$ among vertebrates. Proc. Natl. Acad. Sci. USA 86, 7049-7053 (1989).

73. Meyne, J., Baker, R. J., Hobart, H. H., Hsu, T. C., Ryder, O. A., Ward, O. G., Wiley, J. E., Wurster-Hill, D. R., Yates, T. K., Moyzis, R. K. Distribution of non-telomeric sites of the (TTAGGG) $)_{\mathrm{n}}$ telomeric sequence in vertebrate chromosomes. Chromosoma 99, 3-10 (1990).

74. Tom Strachan, Read Andrew. Human Molecular Genetics, 2nd Edition. ISBN-10: 185996-202-5 (1999).

75. Ford, M., Fried, M. Large inverted duplications are associated with gene amplification. Cell 45, 425-430 (1986).

76. Hyrien, O., Debatisse, M., Buttin, G., de Saint Vincent, B. R. The multicopy appearance of large inverted duplication and the sequence at the inversion joint suggest a new model for gene amplification. EMBO J. 7, 407-417 (1988).

77. Ma, C., Looney, J. E., Leu, T. H., Hamlin, J. L. Organisation and genesis of dihydrofolate 
reductase amplicons in the genome of a methotrexate-resistant Chinese hamster ovary cell line. Mol. Cell. Biol. 8, 2316-2327 (1988).

78. Looney, J. E., Ma, C., Leu, T. H. et al. The dihydrofolate reductase amplicons in different methotrexate-resistant Chinese hamster cell lines share at least a 273-kilobase core sequence, but the amplicons in some cell lines are much larger and remarkably uniform in structure. Mol. Cell. Biol. 8, 5268-5279 (1988).

79. Toledo, F., Le Roscouet, D., Buttin, G., Debatisse, M., Coamplified markers alternate in megabase long inverted repeats cluster independently in interphase nuclei at early steps of mammalian gene amplification. EMBO J. 11, 2665-2673 (1992).

80. Ma, C., Martin, S., Trask, B., Hamlin, J. L. Sister chromatid fusion initiates amplification of the dihydrofolate reductase gene in Chinese hamster cells. Genes Dev. 7, 605-620 (1993).

81. Jacob, F., Brenner, S., Cuzin, F. On the regulation of DNA replication in bacteria. Cold Spring Harbor Symp Quant Biol 28, 329-348 (1963).

82. Huberman, J. A., Riggs, A. D. On the mechanism of DNA replication in mammalian chromosomes. J. Mol. Biol. 32, 327-341 (1968).

83. Handeli, S., Klar, A., Meuth, M., Cedar, H. Mapping replication units in animal cells. Cell 57, 909-920 (1989).

84. Kitsberg, D., Selig, S., Keshet, I., Cedar, H. Replication structure of the human ß-globin gene domain. Nature 366, 588-590 (1993).

85. Burhans, W. C., Huberman, J. A. DNA replication origins in animal cells - a question of context? Science 263, 639-640 (1994).

86. Fangman, W. L., Brewer, B. J. A question of time: replication origins of eukaryotic chromosomes. Cell 71, 363-366 (1992).

87. Church, K. Replication of chromatin in mouse mammary epithelial cells grown in vitro. Genetics 52, 843-849 (1965). 
88. Hsu, T. C., Markvong, A. Chromosomes and DNA in Mus: terminal DNA synthetic sequences in three species. Chromosoma 51, 311-322 (1975).

89. Miller, O. J. Is the centromeric heterochromatin in Mus musculus late replicating? Chromosoma 55, 165-170 (1976).

90. Madan, K., Allen, J. W., Gerald, P. S., Latt, S. A. Fluorescence analysis of late DNA replication in mouse metaphase chromosomes using BudR and 33258 Hoechst. Exp. Cell. Res. 99, 438-444 (1976).

91. Selig, S., Ariel, M., Goitein, R., Marcus, M., Cedar, H. Regulation of mouse satellite DNA replication time. EMBO J. 7, 419-426 (1988).

92. Kuroiwa, Y. et al. Manipulation of human minichromosomes to carry greater than megabase-sized chromosome inserts. Nat. Biotechnol. 18, 1086-1090 (2000).

93. Au, H. C., Mascarello, J. T., Scheffler, I. E. Targeted integration of a dominant neo(R) marker into a 2- to 3-Mb human minichromosome and transfer between cells. Cytogenet. Cell Genet. 86, 194-203 (1999).

94. Mills, W., Critcher, R., Lee, C., Farr, C. J. Generation of an similar to 2,4 Mb human X centromere-based minichromosome by targeted telomere-associated chromosome fragmentation in DT40. Hum. 8, 751-761 (1999).

95. Shen, M. H. et al. A structurally defined mini-chromosome vector for the mouse germ line. Curr. Biol. 10, 31-34 (2000).

96. Auriche, C., Donini, P., Ascenzioni, F. Molecular and cytological analysis of a $5.5 \mathrm{Mb}$ minichromosome. EMBO Rep. 2, 102-107 (2001).

97. Hardling, J., Mirochnitchenko, O. Preclinical studies for induced pluripotent stem cellbased therapeutics. J. Biol. Chem. 2013. Dec. 20.

98. Raimondi, E. Mammalian chromosome engineering: naturally occuring minichromosome platforms in chromosome engineering: an overview. Hadlaczky G (ed.), pp. 41-56 (Humana Press. Methods Mol Biol, 2011). 
99. Perez, C. F., Vanderbyl, S. L., Mills, K. A., Ledebur Jr, H. C. The ACE system: a versatile chromosome engineering technology with applications for gene-based cell therapy. Bioprocessing 3, 61-68 (2004).

100. Ledbetter, S. A., Schwartz, C. E., Davies, K. E., Ledbetter, D. H. New somatic cell hybrids for physical mapping in distal Xq and the fragile X region. Am. J. Med.Genet. 38, 418-420 (1991).

101. Lucchini, R., Sogo, J. M. Different chromatin structures along the spacers flanking active and inactive Xenopus rRNA genes. Mol. Cell. Biol. 12, 4288-4296 (1992).

102. Karpen, G. H., Schaefer, J. E., Laird, C. D. A Drosophila rRNA gene located in euchromatin is active in transcription and nucleolus formation. Genes Dev. 2, 1745-1763 (1988).

103. Kobayashi, T., Yamanaka, T., Jacobs, J. M., Teixeira, F., Suzuki, K. The Twitcher mouse: An enzymatically authentic model of human globoid cell leukodystrophy (Krabbe disease). Brain Res. 202, 479-483 (1980).

104. Suzuki, K., Taniike, M. Murine model of genetic demyelinating disease: The twitcher mouse. Microsc. Res. Tech. 32, 204-214 (1995).

105. Kouprina, N., Earnshaw, W. C., Masumoto, H. \& Larionov, V. A new generation of human artificial chromosomes for functional genomics and gene therapy. Cellular and Molecular Life Sciences 70, 1135-1148 (2013).

106. Kazuki, Y. \& Oshimura, M. Human artificial chromosomes for gene delivery and the development of animal models. Molecular Therapy 19, 1591-1601 (2011).

107. Yamaguchi, S. et al. A method for producing transgenic cells using a multi-integrase system on a human anrtificial chromosome vector. Plos One 6(2), e17267 (2011).

108. Paun, D., Poiana, C., Petris, R., Radian, S., Miulescu, R. D., Constantinescu, G., Orban, C. Multiple endocrine neoplasia type 2A: Case Report. Chirurgia 108(6), 900-3 (2013).

109. Hacein-Bey-Abina, S., Von Kalle, C., Schmidt, M., Mc Cormack, M. P., Wulffraat, N., Leboulch, P., Lim, A., Osborne, C. S., Pawliuk, R., Morillon, E., Sorensen, R., Forster, 
A., Fraser, P., Cohen, J. I., de Saint Basile, G., Alexander, I., Wintergerst, U., Frebourg, T., Aurias, A., Stoppa-Lyonnet, D., Romana, S., Radford-Weiss, I., Gross, F., Valensi, F., Delabesse, E., Macintyre, E., Sigaux, F., Soulier, J., Leiva, L. E., Wissler, M., Prinz, C., Rabbitts, T. H., Le Deist, F., Fischer, A., Cavazzana-Calvo, M. LMO2-associated clonal T cell proliferation in two patients after gene therapy for SCID-X1. Science 302(5644), 415-9 (2003).

110. Harrington, J. J., Van Bokkelen, G., Mays, R. W., Gustashaw, K., Willard, H. F. Formation of de novo centromeres and construction of first-generation human artificial microchromosomes. Nat. Genet. 15, 345-355 (1997).

111. Ikeno, M. et al. Construction of YAC-based mammalian artificial chromosomes. Nature Biotechnology 16, 431-439 (1998).

112. Henning, K. A. et al. Human artificial chromosomes generated by modification of a yeast artificial chromosome containing both human alpha satellite and single-copy DNA sequences. Proceedings of the National Academy of Sciences of the United States of America 96, 592-597 (1999).

113. Basu, J, Stromberg, G., Compitello, G., Willard, H. F., van Bokkelen, G. Rapid creation of BAC-based human artificial chromosome vectors by transposition with synthetic alpha-satellite arrays. Nucleic Acids Research 33, 587-596 (2005).

114. Basu, J., Compitello, G., Stromberg, G., Willard, H. F., Van Bokkelen, G. Efficient assembly of de novo human artificial chromosomes from large genomic loci. BMC. Biotechnol. 5, 21 (2005).

115. Nakashima, H. et al. Assembly of additional heterochromatin distinct from centromerekinetochore chromatin is required for de novo formation of human artificial chromosome. Journal of Cell Science 118, 5885-5898 (2005).

116. Kaname, T. et al Alphoid DNA from different chromosomes forms de novo minichromosomes with high efficiency. Chromosome Research 13, 411-422 (2005).

117. Grimes, B. R., Rhoades, A. A., Willard, H. F. Alpha-satellite DNA and vector composition influence rates of human artificial chromosome formation. Mol. Ther. 5, 
798-805 (2002).

118. Ikeno, M., Suzuki, N., Hasegawa, Y., Okazaki, T. Manipulating transgenes using a chromosome vector. Nucleic Acids Research 37, (2009).

119. Kouprina, N. et al. Cloning of human centromeres by transformation-associated recombination in yeast and generation of functional human artificial chromosomes. Nucleic Acids Res. 31, 922-934 (2003).

120. Suzuki, N., Nishii, K., Okazaki, T., Ikeno, M. Human artificial chromosomes constructed using the bottom-up strategy are stably maintained in mitosis and efficiently transmissible to progeny mice. J. Biol. Chem. 281, 26615-26623 (2006).

121. Carine, K. et al. Chinese-Hamster cells with a minichromosome containing the centromere region of human chromosome-1. Somatic cell and molecular genetics 12, 479-491 (1986).

122. Semprini, S., Troup, T. J., Kotelevtseva, N., King, K., Davis, J. R., Mullins, L. J., Chapman, K. E., Dunbar, D. R., Mullins, J. J. Cryptic loxP sites in mammalian genomes: genome-wide distribution and relevance for the efficiency of BAC/PAC recombineering techniques. Nucleic Acids Res. 35, 1402-1410 (2007).

123. Kennard ML, Goosney DL, Monteith D, Roe S, Fischer D, et al. Auditioning of CHO Host Cell Lines Using the Artificial Chromosome Expression (ACE) Technology. Biotechnology and Bioengineering 104, 526-539 (2009).

124. Kennard ML, Goosney DL, Monteith D, Zhang L, Moffat M, et al. (2009) The Generation of Stable, High MAb Expressing CHO Cell Lines Based on the Artificial Chromosome Expression (ACE) Technology. Biotechnology and Bioengineering 104, 540-553 (2009).

125. Akagi Y, Isaka Y, Akagi A, Ikawa M, Takenaka M, Moriyama T, Yamauchi A, Horio M, Ueda N, Okabe M, Imai E. Transcriptional activation of a hybrid promoter composed of cytomegalovirus enhancer and beta-actin/beta-globin gene in glomerular epithelial cells in vivo. Kidney Int. Apr; 51(4):1265-9 (1997). 
126. Enyu Imaia, Yoshitaka Akagia, Yoshitaka Isakaa, Masahito Ikawab, Masaru Takenakaa, Masatsugu Horia, Masaru Okabeb. Glowing Podocytes in Living Mouse: Transgenic Mouse Carrying a Podocyte-Specific Promoter. Experimental Nephrology 7:63-66 (1999).

127. Sambrook, J., Fritsch, E. F., Maniatis, T. Molecular cloning: a laboratory manual. 2nd ed. Cold Spring Harbor Laboratory Press (1989).

128. Katona, R. L. Dendrimer mediated transfer of engineered chromosomes.Methods Mol. Biol.738:151-60. Doi: 10.1007/978-1-61779-099-7_11 (2011). 


\section{Saját közlemények:}

1. Toth, A., Fodor, K., Praznovszky, T., Tubak, V., Udvardy, A., Hadlaczky, Gy., Katona, R. L. Novel method to load multiple genes onto a mammalian artificial chromosome. Plos One, 2014 Jan 15;9(1):e85565. doi: 10.1371/journal.pone.0085565. eCollection 2014 Jan 15.

2. Tóth, A., Fodor, K., Blazsó, P., Cserpán, I., Praznovszky, T., Tubak, V., Udvardy, A., Hadlaczky, Gy., Katona, R. L. Generation of induced pluripotent stem cells by using a mammalian artificial chromosome expression system. Acta Biologica Hungarica, közlésre elfogadva (2014). 


\section{Magyar nyelvú összefoglaló}

A génterápia napjainkban az orvosi gyakorlat viharos gyorsasággal fejlődő, nagy érdeklődéstől övezett, egyben legvitatottabb területe. Ehhez elengedhetetlenül fontos egy genetikai információ szállítására alkalmas eszköz. Az ideális vektor ismérvei az alábbiakkal foglalhatók össze: 1) ne tartalmazzon olyan DNS-elemeket, amelyek nem kívánatos megváltozása (rekombináció, mutáció) az érintett sejt, szövet vagy szervezet múködését károsan befolyásolja; 2) ne épüljön be a kromoszómákba, a génállomány normális múködését ne befolyásolja; 3) biztosítsa az általa szállított gén(ek) szabályozott működését és (számuk) ellenőrizhetőségét, azaz állandóságát; 4) illetve alkalmas legyen nagyméretü (akár több Mb hosszúságú) gének bevitelére és müködésük biztosítására. E szigorú feltételeket mai ismereteink szerint egyetlen jelenleg használatban lévő mesterséges génhordozó sem teljesíti. Új korszakot nyithat azonban az emlős mesterséges kromoszóma, mint lehetséges génterápiás vektor. A vírus-alapú vektorok hiányosságaival szemben (alacsony hordozó kapacitás, a gazdagenomba történő integráció) az emlős mesterséges kromoszóma szinte korlátlan méretű DNS befogadására és bevitelére képes, valamint nem integrálódik.

Hadlaczky Gyulának és munkatársainak sikerült de novo egér és humán szatellit DNS-alapú mesterséges kromoszómát előállítani (SATAC). Ennek egy feltölthető változata is elkészült, a Platform ACE. Jóllehet a Platform ACE 50-200 fogadóhellyel is rendelkezik - így elvileg lehetségesnek tűnik több génnel történő „feltöltése” - ugyanakkor problémát jelent, hogy minden új gén kromoszómára töltésekor egy új szelekciós markergént is be kellene juttatnunk a sejtbe, hogy a legutoljára bevitt transzgént hordozó sejtvonalakat is szelektálhassuk. Amellett, hogy véges számú antibiotikum rezisztencia markergén áll rendelkezésre, a nem kívánt 
expressziójukkal is számolni kell, különös tekintettel a várható mellékhatásokra.

Munkánk során célul tűztük ki egy olyan génbeviteli eszköz kidolgozását, amely lehetővé teszi az emlős mesterséges kromoszóma több hasznos génnel történő feltöltését úgy, hogy csak egy szelekciós markergén kazettára legyen szükség minden egyes feltöltéshez. Szupertöltő vektornak vagy röviden pST-nek neveztük el ezt a hasznos gének bevitelére előállított új plazmidot. A szupertöltő vektor használata során azt is bizonyítani kívántuk, hogy a szelekciós markergének maradéktalanul eltávolíthatók a sejtekből, így nem okoznak nem kívánt mellékhatásokat a szervezetben. Ezzel biztonságosabbá kívántuk tenni az emlős mesterséges kromoszómát génterápiás alkalmazásokra.

A szupertöltő ciklus első lépésében egy „entry” vektorba építjük a hasznos, illetve terápiás gént. Ebben az „entry” vektorban az expressziós kazetta tartalmaz egy multi-klónozó helyet (MCS = multi-cloning site), amelyet egy CMVIE-csirke béta-aktin-béta-globin hibrid promóter és egy SV40 polyA szignál szekvencia határol. Két élesztő homing endonukleáz (I-Ceu és PI-PspI) hasítóhelye segíti a plazmidban a transzgént hordozó expressziós kazetta kivágását, majd tovább mozgatását a mesterséges kromoszómára töltés következő vektorába, az ACE targetáló plazmidba (ATV; ACE targeting vector). Ez utóbbi vektor ugyanúgy hordozza az említett két enzim hasítóhelyét, így könnyen átvihető a transzgénünket hordozó megfelelő fragment. A kromoszómára töltéshez a dolgozat tárgyát képező, újonnan előállított pST elnevezésű ATV-t használtuk, amely egy promóter nélküli neomycin antibiotikum rezisztencia gént és egy HSV-TK (Herpes simplex virus-thymidine kinase) expressziós kazettát tartalmaz. Az említett régiót két, direkt orientációban elhelyezkedő LoxP hely határolja. Egy kínai hörcsög ovárium (CHO) sejtvonalban két jól nyomon követhető pST plazmid konstrukciót töltöttünk a mesterséges kromoszómára. Az első szupertöltő plazmid az mCherry gént hordozta. Kromoszómára töltése 
egy módosított lambda integráz (ACE integráz) által végrehajtott helyspecifikus integráció segítségével történt, amely a mesterséges kromoszómán lévő attP és a szupertöltő vektoron jelenlévő attB felismerőhelyek között jött létre. Az enzim egy módosításnak köszönhetően nemcsak bakteriális környezetben, hanem emlős sejtben is képes az integrációt katalizálni. Az enzim a pCXLamIntROK plazmidról tranziensen fejeződik ki, mivel a transzfekció során a targetáló vektorral együtt ezt is bejuttatjuk a sejtekbe. A feltöltés következtében a promóter nélküli neomycin rezisztencia gén promótert szerez magának - miután beépült az emlős mesterséges kromoszóma fogadóhelyére -, ami lehetővé teszi a transzgént hordozó sejtvonalak G418 szelekcióval történő kiválasztását. Így olyan sejtvonalat hoztunk létre, amely a mesterséges kromoszómáról expresszálta a piros fluoreszcens fehérjét. A létrehozott sejtvonalakat helyspecifikus integrációt kimutató PCR reakcióval, FISH kísérletekkel és fluoreszcens mikroszkópia segítségével ellenőriztük. Az első szupertöltő ciklus végén a Cre rekombináz tranziens expressziójával eltávolítottuk a neomycin-HSV-TK expressziós kazettát a sejtekből. Ezzel a mesterséges kromoszóma egy következő gén befogadására képes anélkül, hogy egy újabb szelekciós markergént alkalmaznánk. A kromoszómára töltés következő lépésében a bétagalaktozidáz enzim génjét, a LacZ-t tartalmazó pST plazmidot töltöttük fel a már mCherry-t expresszáló sejtvonalban a kromoszómára. Így az ACE integráz segítségével ismét helyspecifikus integrációt hajtottunk végre. Az mCherry és a LacZ gént a mesterséges kromoszómán hordozó sejtvonalakat kiválogattuk és a legmegfelelőbb klónt helyspecifikus integrációt kimutató PCR reakcióval, FISH kísérletekkel, fluoreszcens mikroszkópos vizsgálatokkal, illetve LacZ festés segítségével azonosítottuk.

Eredményeink alapján elmondhatjuk, hogy az emlős mesterséges kromoszóma - amennyiben szükséges - akár több génnel is feltölthető, egyetlen szelekciós markergén kazetta alkalmazásával. Több gén egyidejü jelenléte az emlős mesterséges kromoszómán mind a 
komplex genetikai és daganatos betegségek kezelése esetében, mind a több transzgént hordozó és kifejező állatok és növények előállításában, sőt biokémiai szignáltranszdukciós útvonalak tanulmányozásához is elengedhetetlen. Eredményeink alapján elmondható, hogy az emlős mesterséges kromoszóma és a szupertöltő rendszer kombinációja alkalmassá válhat mind alapkutatási, mind pedig terápiás célú felhasználásra az említett kutatási területeken. 


\section{English summary of the Ph.D. thesis}

Nowadays the field of gene therapy is rapidly developing in clinical applications and it draws public attention, but it is still a controversial issue. To achieve safe and effective gene therapy, it is indispensable to develop a novel vector system, which has a high genetic material carrying capacity. The criteria of an ideal vector are the following: 1) it shouldn't contain DNA elements, which are prone to recombination and/or mutation and could cause harm to cells, tissues or organs; 2) it shouldn't integrate into, and influence the normal function of the host genome; 3) it should ensure that the the delivered gene(s) has a controlled function and copy number; 4) it should have a vast amount (up to Mb sized) of genetic material carrying capacity. As far as we know, presently there is no proper gene carrier, which meet these strict requirements. Therefore, the mammalian artificial chromosome may open a new era, as a novel gene therapy vector. In contrast to the deficiencies of the virus-based vectors (low transgene carrying capacity, integration into the host genome) the mammalian artificial chromosome has an unlimited transgene carrying capacity and it doesn't integrate into the host genome.

Gyula Hadlaczky and his colleagues successfully produced de novo mouse and human satellite DNA-based artificial chromosomes (SATACs). Recently, a novel version of SATAC was developed, which carries multiple acceptor sites for gene delivery. This chromosome is called Platform ACE. The Platform ACE contains 50 to 200 acceptor sites and therefore, it is theoretically possible to load many genes onto this chromosome. However, there is a major problem inherent in the present system, since it is necessary to use a new antibiotic resistance gene for each transgene-loading onto this Platform ACE. Moreover, the number of presently available antibiotic marker genes is limited and their overexpression could lead to undesired 
side-effects.

During our experiments, we aimed to develop a new gene loading system, which enables the loading of Platform ACE with many genes by using only one selection marker gene cassette. We named this novel plasmid vector as superloading vector or shortly pST.

In the first step of our superloading system, we have an „entry” vector, into which the useful gene is cloned. This „entry” vector carries an expression cassette that consists of a multi-cloning site (MCS) flanked by a CMVIE-chicken beta-actin-beta-globin hybrid promoter and an SV40 polyA signal sequence. There are two yeast homing endonuclease (I-Ceu, PI-PspI) recognition sites outside the expression cassette. We use these sites to deliver the transgene expression cassette from the entry vector into the ACEs-targeting ATV vectors, which are also carrying these recognition sites. In the experiments described here, we developed the pST ATV plasmid, which contains a promoterless neomycin antibiotic resistance gene and a HSV-TK (Herpes simplex thymidine kinase) expression cassette flanked by LoxP sites in direct orientation. We loaded two, well-detectable constructs into a Platform ACE-carrying Chinese hamster ovary (CHO) cell line. The first superloading plasmid carried the mCherry gene. The pST vector together with its cargo is loaded onto the Platform ACE by the ACE integrase. This enzyme achieves the loading event by performing a site-specific recombination between the attP (on the Platform ACE) and the attB sites (on the pST ATV). The ACE integrase is based on the enzyme lambda integrase, which has been modified. The modification renders the integrase functionally independent of bacterial host cell factors and capable of operating in a mammalian context. The ACE integrase is transiently expressed from the pCXLamIntROK plasmid, which is co-transfected with the pST ATV vector into the target cells. After the loading procedure, the promoterless neomycin resistance gene replaces the puromycin resistance gene on the Platform ACE and acquires its promoter. 
Therefore, the transgene carrying cell lines become G418-resistant. In this way, we successfully produced red fluorescent protein expressing cell lines. We checked these established cell lines by using PCR specific to the integration event, FISH experiments and fluorescence microscopy. At the end of the first superloading cycle, we removed the whole neomycin-HSV-TK expression cassette from the cells by transiently expressing the Cre recombinase. Therefore, the ACE was able to receive another transgene, without the application of a new selection marker gene. In the second superloading cycle, we loaded the LacZ containing pST plasmid onto the Platform ACE, which was already carrying the mCherry. We successfully induced site-specific integration event again. We selected the cell lines, which were carrying both the mCherry and the LacZ genes on the Platform ACE, using PCR specific to the integration event, FISH expreiments, fluorescent microscopy and LacZ staining.

Based on our results, we can conclude that our artificial chromosome can be loaded with several transgenes by using only one selectable marker gene cassette. The ability to load several genes onto the Platform ACE could be important for the treatment of complex genetic diseases and cancer, for producing transgenic animals with multiple genes and also for studying complex biochemical signal transduction pathways. We believe that our mammalian artificial chromosome combined with this novel superloading system could be a suitable gene-carrier for future basic research and therapeutic applications in the above mentioned research fields. 